Article

\title{
Finding an Effective Treatment for Sustainable Chinese Lan- guage Learning in Japan: A Comparative Study on Motivation of Different Ages
}

\author{
Qiao-Yu Cai ${ }^{1, *}$
}

1 National Taichung University of Education; iku@mail.ntcu.edu.tw

* Correspondence: iku1212@hotmail.com; iku@mail.ntcu.edu.tw

\begin{abstract}
Sustaining learners' motivation to keep learning has been concerned for over 60 years in education and SLA. Most research focusing on Japanese university students has contributed lots of theoretical and practical developments, but research focusing on motivations of non-traditional adult learners and those under 18-year-old to learn Chinese is still little even though previous research findings have proved age is one of the key variables influencing learning besides nationalities and Chinese language levels. In order to find an effective treatment for sustainable Chinese language learning in Japan, this study utilized a survey method to analyze the types of Japanese learners' motivation to learn Chinese via analysis of a moment structures (AMOS), and to compare the differences of the motivation via one-way ANOVA. This study revealed that Japanese learners' motivation to learn Chinese consists of eight common types, which are "instrumental motivation", "personal orientation", "identified regulation", "Chinese cultural productions", "integrating into Chinese community", "external regulation", "social responsibility", and "Chinese for academic purposes". Also, there are similarities and differences existing in the eight motivation types among the Japanese children, adolescents, (non-) traditional adult learners of Chinese as a foreign language (CFL). The findings contribute the understanding of motivation types and differences among the four aged Japanese learners to teachers of teaching Chinese to speakers of other languages (TCSOL), and to future research further exploring how differently aged Japanese learners can have and use a higher motivation as a main drive to learn Chinese language as a lifelong business.
\end{abstract}

Keywords: motivation for learning Chinese, Japanese learners of Chinese, teaching Chinese to Japanese learners, teaching Chinese to kids and adolescents, teaching Chinese to adults

\section{Introduction}

Sustaining learners' motivation has been a basic but important issue in primary education [1-3], secondary education [4-6], higher education [7-9], and SLA [10-15] due to the recognition of motivational impact of the main components of the classroom learning situation, such as the teacher, the curriculum, and the learner group [10]. In Taiwan, the number of Japanese learners of Chinese has always been one of the highest; in Japan, there is an increasing number of Japanese learners of Chinese, and the population of Japanese learners of Chinese is only second to that of Japanese learners of English in Japan. Nin and Cai [16] believed that clarifying the motivations of Japanese people to learn Chinese will be of great significance for planning future innovative Chinese language curriculum and teaching materials for Japanese learners, which in fact motivates the present study to find an effective treatment for sustainable Chinese language learning through comparing differently aged Japanese learners to understand their motivations to learn Chinese as s foreign language (CFL).

Compared to motivation research in the fields of English and education, little research is conducted in the teaching Chinese to speakers of other languages (TCSOL). Nevertheless, as TCSOL courses in the world spring up like mushrooms after rain, research of 
Chinese language learning motivation achieves fruitful results and consequently the importance of this issue remains in focus. Regarding the motivations of Japanese people to learn Chinese, the majority of research has involved Japanese university students, who are treated as traditional adult learners, and the findings have helped to improve teaching CFL to Japanese learners. However, the present study found that research regarding motivations to learn Chinese among Japanese children younger than 18 years and salaried Japanese people, who are treated as non-traditional adult learners, is not widespread, even though salaried Japanese people are most likely to learn Chinese for job and sightseeing purposes. Previous related studies confirmed that age is an important variable affecting learning CFL in addition to nationality and Chinese language proficiency. Although motivations to learn Chinese that vary with age are diverse and complicated, few studies have explored motivations to learn Chinese among differently aged Japanese people. This is undoubtedly a knowledge gap in the field of teaching CFL to Japanese learners. Therefore, the present study aims to analyze the motivations of Japanese people to learn Chinese via Analysis of Moment Structures (AMOS) and to compare differences in motivations via a one-way ANOVA. Once the motivations of differently aged Japanese learners of CFL are well understood, it may be helpful for TCSOL teachers to effectively enhance their motivations to learn Chinese for sustainable Chinese language learning in Japan.

\section{Literature Review}

Theories on motivations to learn foreign languages and findings of previous related studies have also been applied to TCSOL since 1990s when Japanese research on motivations to learn foreign languages has been conducted [17-20]. As far as Chinese L2 learners' ages and their motivations to learn Chinese are concerned, He [21] pointed out that foreign students learn Chinese for wanting to be translators, for doing business in China, and for personal interest in Chinese culture. Their motivations are different from those of native Chinese speaking children acquiring their mother tongue. Xia [22] found that Chinese-heritage students' motivations to learn Chinese are constantly evolving with ages. For example, younger students' motivations to learn Chinese are influenced by interests, learning content, teachers' comments, parents' requirements, as well as their weak selfcontrol ability; these five factors make them feel they are forced to learn Chinese. Adolescent Chinese-heritage students, however, realize that the main priority to learn Chinese is to prepare themselves for jobs and further studies, followed by obeying parents' requests, understanding Chinese culture, and engaging themselves in social communication. Hou [23] found that the older the students become, the more obvious their social motivations are, such as minding their status in the class, and comparing their Chinese test scores with other students'. In addition, older students hope to find good jobs in the future, so they have stronger instrumental motivations. Moreover, older students are afraid that their Chinese grades are worse than those of younger students, so they are active to learn Chinese to gain other students' respect. Such motivation is called "prestige motivation", which is one of the key factors for older students to learn Chinese. A questionnaire survey, conducted among 761 foreign students studying in China, reported that around $75 \%$ of the students studied Chinese for occupations, about $25 \%$ for understanding China, and about $17 \%$ for being Chinese teachers or conducting Chinese language research [18]. Shi and Wan [19] compared foreign students studying in China and learning Chinese characters; they found that students from West Asia and Europe have the highest interest in learning Chinese characters, followed by students from Southeast Asian countries, and finally by Japanese and South Korean students. This is because students from "non-Sphere of Chinese language influence" worship Chinese culture, literature and art, or originally are fascinated with Chinese characters. On the contrary, Japanese and South Korean students being in the "Sphere of Chinese language influence" learn Chinese characters from 
an early age in their own countries; therefore, knowing Chinese characters does not motivate them to learn Chinese. $\mathrm{Xu}$ [24] conducted a survey of foreigners studying Chinese in universities and other educational institutions; she found that their main motivation to learn Chinese has to do with business, trade, cultural exchanges, China studies, job hunting, and life needs, accounting for $70 \%$; to enter higher education institutes for further study is the secondary motivation, accounting for $20 \%$; the third one is to pursue a language career, accounting for 3\%; the fourth one is to study Chinese linguistics, accounting for only $1 \%$, and unidentifiable motivations accounted for $5 \%$. Lu [25] divided motivations to learn Chinese into five categories: For career, occupation, education, academic, and other purposes. $\mathrm{Li}$ [26] believes that foreigners' motivations to learn Chinese is to understand China - a mysterious country, to travel in China, to seek employment, to study further in China, to study China, and to appreciate and spread Chinese language and culture. These, generally speaking, can be regarded as the common motivations to learn Chinese. Additionally, a study, by Ding and Wu [17] found higher instrumental motivations in foreign students, who have studied Chinese for a longer period; these students prefer better communication with Chinese people and economic exchanges between countries. Because motivations to learn Chinese vary, Tsai et al. [27] suggest that teachers should adopt different strategies to motivate students. For students whose motivation is for further studies, teachers can use praise and positive tone to enhance their self-confidence and encourage them to learn. For students with a business purpose, teachers should pay more attention to their current and future work needs and strengthen their four language skills. For passive learners such as elementary and middle school students who learn upon parents' requests, teaching strategies should focus on arousing their interests to learn Chinese.

With respect to Japanese CFL learners who are under 18 years old, Xue and Chen [28] surveyed 140 elementary and middle school students at a Chinese school in Japan in October 2009; 80\% had Japanese as their first language; nearly $70 \%$ were motivated to learn Chinese because of parents' advice; about $28 \%$ feel to study and work beneficial; about $25 \%$ identify themselves as Chinese; around $10 \%$ want to communicate with Chinese people, and only about $0.9 \%$ want to understand Chinese culture. Hiraoka et al. [29] analyzed the correlations between Japanese CFL learners' motivations and their Chinese scores by 10 items and found that the higher the motivations, the higher the Chinese scores. The items include "Because of Chinese characters, I think learning Chinese is easy", "Learning Chinese is fun", "Learning Chinese is cool", "Learning Chinese for going to China one day", "Learning Chinese is beneficial for future jobs.", "I want to speak Chinese", "Learning Chinese is good for job hunting", "No exam in Chinese classes", "Not interested in other subjects" and "Interested in Chinese classics". Sugiue [30] conducted a study on online language exchanges for 9 months; the participants were senior high school students who were learning both Chinese and Japanese at three high schools in China and Japan respectively. Sugiue [30] found that 95\% of Japanese high school students believed that online language exchanges were very conducive to improving Chinese communication skills. These students with such experiences recognized the meaning and value in learning Chinese; hence their motivations to learn Chinese increase.

As far as Japanese learners of Chinese in universities are concerned, Xia [31] categorized their motivations to learn Chinese into four types: curiosity, aimlessness, practicality, and ideality. Due to the fact that both Chinese and Japanese share common Chinese characters, so Japanese college students think that Chinese is easy to learn and course credits easy to get; this fact makes them more willing to learn Chinese. Such a motivation, called "passive motivation", is unique to Japanese college students [32-34]. Li [35] exploring the correlation between Japanese college students' Chinese language learning motivation and performance in a psychological perspective found that Japanese college students with practical attitudes, self-expectation, and internal and external motivations are positively correlated with their Chinese language performance. Nin and Cai [16] analyzed the 
differences in Chinese language learning motivation between freshmen and sophomores, as well as male and female college students using the Independent Samples $t$ Test. The study found freshmen's passive influence motivation was significantly higher than sophomores', and male college students are significantly more motivated than female ones in multilingual comparison. Mao and Fukuda [36] compared the motivations of Japanese CFL learners with those of Chinese learners studying Japanese; they found that job hunting, work, self-practice, and international communication and understanding were the main factors that explain why Japanese CFL learners tend to learn Chinese; interest in Japan and Japanese culture, and influence from others or the environment explain why Chinese JFL learners tend to learn Japanese. Tao [37] conducted a questionnaire survey on 328 students studying Chinese at five Japanese universities, and found that the most popular choice among male college students is "to obtain course credits", accounting for about $60.0 \%$; the most popular choice among female college students is "To make traveling to China easier ", accounting for about 47.2\%. Secondly, "To increase opportunities for promotion when working in the future " is the second motivation for both male $(41.2 \%)$ and female (44.8\%) college students. The third place for male college students' motivation to learn Chinese is "To make traveling to China easier", accounting for about 36.4\%, and for female college students, the third motivation to learn Chinese is "To communicate with people who speak Chinese and make friends more easily " and "to obtain course credits", accounting for about $42.9 \%$.Overall, the male college students' motivation to learn Chinese tends to be aimless, while female college students' motivation to learn Chinese is practical [37].

To sum up, it can be seen that the study of learning motivation not only has received a lot of attention and continues to be explored by scholars and experts in the field of foreign language teaching since its inception, but has also accumulated a certain amount of research results in the past 30 years. Tan [20] pointed out that the research on Chinese L2 learners' motivations in non-native Chinese speaking environments has been increasing, a fact that shows this particular issue has caught more and more attention beyond mainland China to overseas, but most research focus used descriptive statistics and studied Chinese L2 learners in one or several particular institutes to explore their motivations to learn Chinese, due to difficulty in conducting large-scale investigations. In the hope of understanding how the motivations of learners at different age groups may be conducive to Chinese language teaching to make learners more involved in learning activities [38,39], this study assumed that differences in motivation exist among differently aged Japanese CFL learners (children, adolescents, traditional and non-traditional adult learners) in addition to personal variables, such as gender, environment, degree, occupation and others. This is because non-traditional adult learners differ from traditional adult learners in work and social experience, and multiple roles played in life [40-44]. Given the research background and literature review, this study has a clear global of analyzing the types of Japanese learners' motivations to learn Chinese via AMOS, comparing differences of the motivations via a one-way ANOVA, and providing current research findings as an effective treatment for sustainable Chinese language learning in Japan.

\section{Methods}

\subsection{Participants}

The participants in this study were the different aged Japanese CFL learners in Japan. Approximately 900 copies of the "Questionnaire for Japanese Learners' Motivation toward Learning Chinese" (Q-JLMLC) with three languages (Chinese, Japanese, and English) (Appendix A) were distributed in Japan, and 616 useable responses were received. The 616 respondents were 293 elementary and secondary school students at two Chinese schools, 92 Japanese university students (traditional Japanese CFL adult learners) enrolled 
in Chinese courses, and 231salaried Japanese people and retirees (non-traditional Japanese CFL adult learners) at Chinese language institutes. Participants' ages ranged from 7 to 83 years with $80.5 \%$ Japanese, $16.9 \%$ Japanese-born Chinese, 2.6\% Japanese-born Asian. Their first language is Japanese no matter which ethnicity it is. Table 1 summarizes the participants' demographic information.

Table 1. Demographic Information about Participants

\begin{tabular}{|c|c|c|c|c|}
\hline Category & $\begin{array}{l}\text { Level } \\
\end{array}$ & Number & Proportion & Average age \\
\hline \multirow[t]{4}{*}{ Age } & $\begin{array}{c}\text { Elementary school students } \\
\text { (children) }\end{array}$ & 167 & 27.1 & 10.71 \\
\hline & $\begin{array}{c}\text { Secondary school students } \\
\text { (adolescents) }\end{array}$ & 126 & 20.5 & 13.87 \\
\hline & $\begin{array}{c}\text { Japanese university students } \\
\text { (traditional Japanese CFL } \\
\text { adult learners) }\end{array}$ & 92 & 14.9 & 20.28 \\
\hline & $\begin{array}{l}\text { Salaried Japanese people and } \\
\text { retirees (non-traditional Japa- } \\
\text { nese CFL adult learners) }\end{array}$ & 231 & 37.5 & 45.90 \\
\hline \multirow[t]{3}{*}{ Gender } & Male & 220 & 35.7 & \\
\hline & Female & 387 & 62.8 & \\
\hline & Unreported & 9 & 1.5 & \\
\hline \multirow[t]{3}{*}{ Ethnicity } & Japanese & 496 & 80.5 & \\
\hline & Japanese-born Chinese & 104 & 16.9 & \\
\hline & Japanese-born Asian & 16 & 2.6 & \\
\hline \multirow{6}{*}{$\begin{array}{c}\text { Chinese } \\
\text { language } \\
\text { proficiency }\end{array}$} & Introductory & 43 & 7.0 & \\
\hline & Basic & 176 & 28.6 & \\
\hline & Intermediate & 250 & 40.6 & \\
\hline & Advanced & 112 & 18.2 & \\
\hline & Others & 11 & 1.8 & \\
\hline & Unreported & 24 & 3.9 & \\
\hline
\end{tabular}

\subsection{Instrument}

Designing the Questionnaire for Japanese Learners' Motivation toward Learning Chinese for expert judgment (Q-JLMLC-EJ) with three languages (Chinese, Japanese, and English) was the first step. To lay a stable foundation for this study, the related literature and theories for motivation to learn foreign languages and items in previous foreign language learning motivation questionnaires [40-50] were analyzed and served as the items for the Q-JLMLC-EJ. 10 collective TCSOL-related scholars and specialists in Taiwan and Japan were invited to advise on items in the Q-JLMLC-EJ. This study utilized the Content Validity Index (CVI), a respected tool to evaluate the content validity of a scale proposed by Waltz, Strickland and Lenz [51], to ensure the items are appropriate.

To calculate the CVI value, the invited scholars and specialists are asked to rate the applicability of each item on a 4-point scale. There are several variations of labeling the 4 ordinal points, but the scale used most often is 1 = inapplicable, 2 = applicable after modification, 3 = applicable, and 4 = very applicable [52]. For each item, then, its CVI value is computed as the number of scholars and specialists giving a rating of either 3 or 4 , divided by the number of scholars and specialists, that is, the proportion in agreement about applicability. The formula for the CVI value of each item is CVI $i=\frac{n}{N 10}$. " $i$ " stands for each item's number, " $n$ " stands for the number of scholars and specialists rating an item at 3 or 
4, and "N10" stands for the 10 TCSOL-related scholars and specialists. Based on the formula, the sum of each CVI value is able to be computed out and (CVI 1 (88) equals 76.3. Finally, 76.3 ( $\mathrm{CVI}_{1 \sim 88}$ ) divided by 88 (the number of item) is approximately equal to .867 (Total CVI), which is larger than .80. Therefore, the results demonstrated good content validity for the Q-JLMLC-EJ. Item 25 "Everybody in school has to learn Chinese." and Item 42 "Learning Chinese is required in my school." are similar, so Item 42 was eliminated. The concept of Item 24 "My parents and teachers want me to learn Chinese." overlaps with that of Item 76 "I learn Chinese because my parents want me to learn it.", so Item 76 was eliminated and Item 24 was broken down to be two separate items: "My parents want me to learn Chinese." and "My teachers want me to learn Chinese." To avoid respondents from answering without thinking, items in the same categories were scrambled. The developed “Questionnaire for Japanese Learners' Motivation toward Learning Chinese" (Q-JLMLC) with Chinese, Japanese, and English languages and a 5-point Likerttype scale were adopted to measure learners' responses, including the response degree of impact: "Above 80\%", "60 79\%", "40 59\%”, "20 39\%”, and "Under 19\%." The degree of impact was given 5 to 1 points accordingly. In addition, the demographic questions, such as gender, age, identity, nationality, school or affiliation, marital status, duration of learning Chinese in Japan, Taiwan, China and other countries, and self-evaluation on Chinese level, were also included in the Q-JLMLC. The Japanese CFL learners would be assessed by the Q-JLMLC on how motivated they are to learn Chinese is.

Next, to measure the correlation of each item with the underlying construct, to differentiate between respondents having high total and low total scores on summated fivepoint Likert scale items [53], and to eliminate items which are not discriminative, the item analysis was run through IBM SPSS Statistics 24.0 for Windows in the present study. After that, internal consistency reliability analysis was utilized to judge how well the items on the Q-JLMLC that were proposed to measure the same construct produce similar results.

In the item analysis, the critical ratio of extreme-group for items is $p<.05$ which reaches the level of significance. This means the questions are able to precisely reflect the action of subjects. In test of homogeneity, the (corrected) item-total correlation of items is above .30 , and this indicates that the corresponding item correlates very well with the scale overall [54] except Items 25 "I know that learning Chinese is important for me, but I do not enjoy learning it" (the critical ratio: 2.263 and the (corrected) item-total correlation: $.120(.098)$ ), and 26 "I learn Chinese because learning Chinese is enjoyable." (the critical ratio: 10.280 and the (corrected) item-total correlation: $.287(.258)$ ), and $\mathrm{p}<.01$ which reaches the level of significance. The reliability value (Cronbach's alpha if item deleted) of Items 23 "I learn Chinese because my Chinese teacher(s) is (are) good.", 25, 26, 28 "I feel bad if I couldn't perform well in Chinese classes.", 41 "Learning Chinese is useful when I travel in Chinese-speaking countries.", 44 "I learn Chinese because I am a Japanese-born Chinese.", 61 "I learn Chinese to broaden my horizons.", 64 "My parents want me to learn Chinese.", 65 "Everybody in school has to learn Chinese.", 66 "My teachers want me to learn Chinese.", 73 "I learn Chinese to have a break from home or work routine.", 75 "I learn Chinese to keep up with others in my family.", 77 "I learn Chinese to get away from boredom.", and 78 "I learn Chinese because my spouse wants me to learn it." is not less than the Cronbach's Alpha value .970. Hence, these items are eliminated and others are kept to run the exploratory and confirmatory factor analysis via the AMOS to analyze the types of Japanese learners' motivations to learn Chinese.

\section{Results}

\subsection{The Types of the Different Aged Japanese Learners' Motivation for Learning Chinese}

This study analyzed the types of the different aged Japanese learners' motivations to learn Chinese by means of exploratory and confirmatory factor analysis. The purpose was both to extract common factors to classify the motivation types and to construct validity 
of the scale. Thus, principal components analysis was utilized to estimate factor loadings. Normally, factor loadings should be larger than .40 [54,55]. Items, of which the factor loadings are lower than .40, would be eliminated because the items are invalid and have a low correlation with other items in the same common factor.

In the first exploratory factor analysis (EFA), the twelve common factors are extracted. The factor loadings of the items are larger than .40 except in Items 19 "I learn Chinese to make myself speak Chinese as well as native Chinese speakers do.", 50 "I learn Chinese because no Chinese courses were offered during previous education.", 63 "I learn Chinese to get entrance to another school or college.", 9 "I learn Chinese because I am interested in Chinese literature.", 32 "I learn Chinese because I feel good when I resolve the difficulties.", 20 "I learn Chinese because I am interested in Chinese courses.", 2 "I learn Chinese to write Chinese research papers comparable to those written by native Chinese speaking peers." and 67 "I learn Chinese because I want people to think I can speak Chinese well.". Also, at least 3 items in a common factor are necessary because one or two items will fail to reflect the feature of the common factor. Thus, in additional to items 19, 50, 63, 9, 32, 20, 2 and 67, Items 72"I learn Chinese because the people I am familiar with also learn Chinese." and 71 "I learn Chinese because people I am acquainted with can speak Chinese fluently." are also eliminated. The cumulative explained variance is $63.917 \%$ 。

Based on the result of the first EFA, the rest of the 62 items are compiled by the second EFA. The result of the second factor analysis showed the elven common factors are extracted. The factor loadings of the items are larger than .40 except in Items 34 "I learn Chinese because I feel good when I do things well in Chinese." and 37 "I learn Chinese to keep up with others who speak Chinese fluently.". However, only items 16 "I learn Chinese because I can meet new people and make friends in the Chinese class." and 17 "I learn Chinese because I like using Chinese to deal with difficulties." are in the same common factor, so the two items are also eliminated in addition to Items 34 and 37 . The cumulative explained variance is $65.109 \%$.

Based on the result of the second EFA, the rest of the 58 items are compiled by the third EFA. The result shows that the factor loadings of the nine common factors extracted is larger than .40. The cumulative explained variance is $65.078 \%$.

In order to test the factorial structure of observed variables and verify which observed variable is related to which latent variable, the confirmatory factor analysis (CFA) is run in this study. In the CFA, Item 3"Learning Chinese is a preparation for getting a job.", 22 "I learn Chinese because I want to be a good Chinese teacher.", 24"I learn Chinese to quench my thirst for Chinese knowledge.", 36"I learn Chinese because my Chinese textbooks are good.", 39"I learn Chinese in order to pass a Chinese Band Test.", 42"I learn Chinese in order to emigrate to Chinese-speaking countries.", 43"I learn Chinese because I am interested in Chinese cultures.", 45"I learn Chinese to overcome the frustration in daily life.", 46"I learn Chinese because I want to increase the mutual understanding among peoples in the world." ,53"I learn Chinese because I want to show my teachers that I can learn Chinese.", 56"I learn Chinese to help my children learn Chinese.", 58 "I learn Chinese to increase my job competence.", 69"I learn Chinese to get away from loneliness.", 74"I learn Chinese to get ready for changes in my family.", 76"I learn Chinese to find a good job later.", 80 "I feel bad if I couldn't speak Chinese in Chinese classes.", 84 "I learn Chinese to feel a sense of achievement.", 85 "I learn Chinese because acquiring good Chinese skills is a stepping-stone to one's success in life." and 86 "I learn Chinese because learning Chinese can challenge me." are eliminated according to modification indices (M. I.). This is because the concepts of these items are similar with other items, resulting in the GFI's and AGFI's values less than .8 and RMSEA larger than .08. Also, Items 1 "I learn Chinese to live up to a saying which goes, 'Never too late to learn'.", 29 "I learn Chinese because it is easy to get credits in the Chinese class.", 18 "I learn Chinese because there are Chinese characters in Chinese and Japanese.", 33 "I learn Chinese because learning 


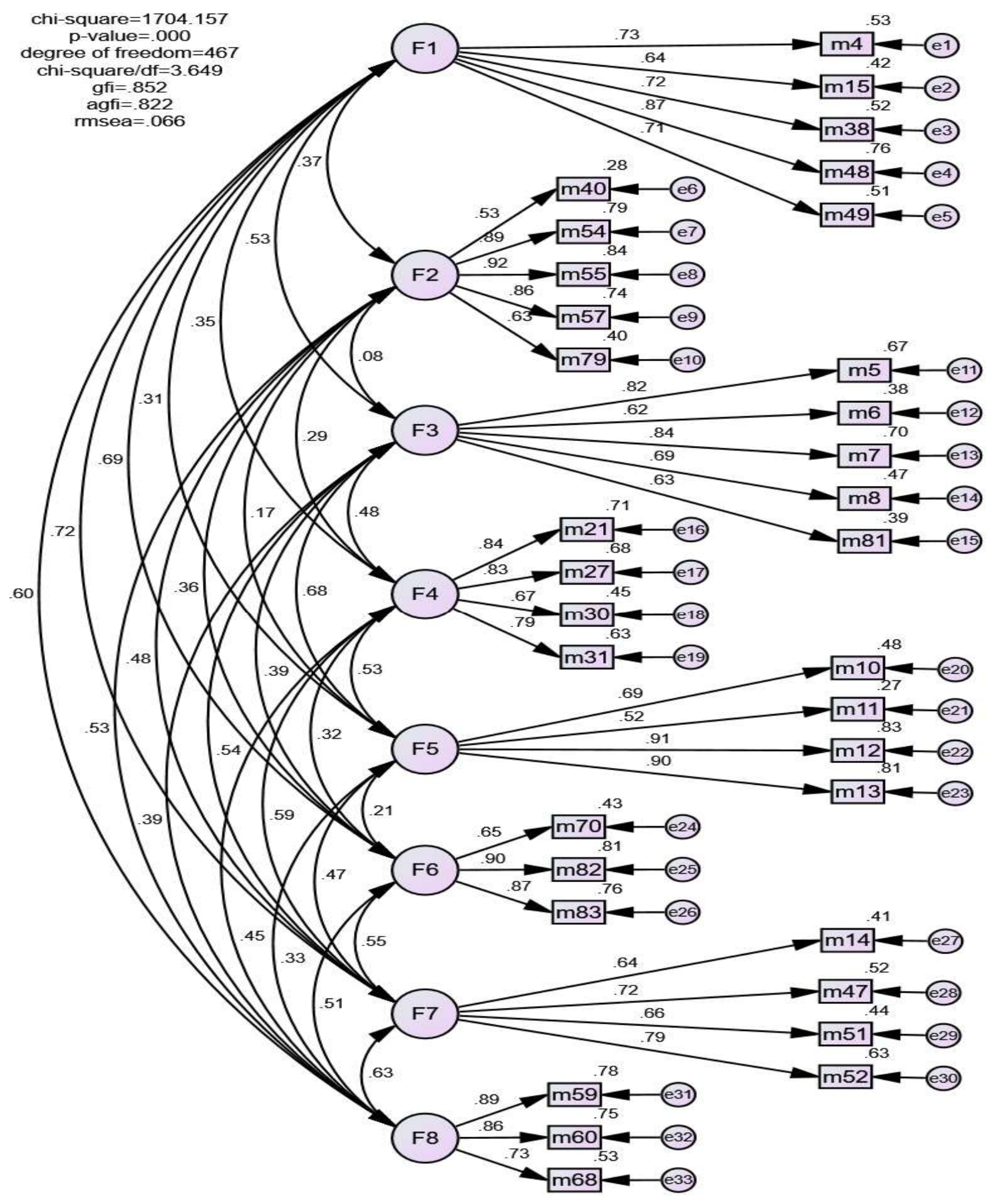

Chinese is easier than learning English or other foreign languages.", 35 "I learn Chinese because I like my fellow students in the Chinese class." and 62 "I learn Chinese to feel occupied rather than doing nothing." are eliminated because the SMC values are lower and these items resulted in Average Variance Extracted (AVE) less than .5, signifying the convergent validity is poor [55-57]. Figure 1 and Table 2 show the result of the CFA model after modifying. 
Figure 1. Confirmatory factor analysis of the Q-JLMLC

Table 2. The CFA Result

\begin{tabular}{|c|c|c|c|c|c|}
\hline $\begin{array}{l}\text { Latent } \\
\text { variables }\end{array}$ & $\begin{array}{l}\text { Observed } \\
\text { variables }\end{array}$ & $\begin{array}{l}\text { Standardized } \\
\text { factor loadings }\end{array}$ & $\begin{array}{l}\text { Squared } \\
\text { Multiple } \\
\text { Correlations } \\
\text { (SMC) }\end{array}$ & $\begin{array}{l}\text { Composite } \\
\text { Reliability } \\
\text { (CR) }\end{array}$ & $\begin{array}{l}\text { Average } \\
\text { Variance } \\
\text { Extracted } \\
\text { (AVE) }\end{array}$ \\
\hline \multirow[t]{5}{*}{ F1 } & $\mathrm{m} 4$ & .73 & .53 & \multirow[t]{5}{*}{.86} & \multirow[t]{5}{*}{.55} \\
\hline & m15 & .64 & .42 & & \\
\hline & $\mathrm{m} 38$ & .72 & .52 & & \\
\hline & $\mathrm{m} 48$ & .87 & .76 & & \\
\hline & $\mathrm{m} 49$ & .71 & .51 & & \\
\hline \multirow[t]{5}{*}{ F2 } & $\mathrm{m} 40$ & .53 & .28 & \multirow[t]{5}{*}{.88} & \multirow[t]{5}{*}{.61} \\
\hline & $\mathrm{m} 54$ & .89 & .79 & & \\
\hline & m55 & .92 & .84 & & \\
\hline & $\mathrm{m} 57$ & .86 & .74 & & \\
\hline & $\mathrm{m} 79$ & .63 & .40 & & \\
\hline \multirow[t]{5}{*}{ F3 } & $\mathrm{m} 5$ & .82 & .67 & \multirow[t]{5}{*}{.84} & \multirow[t]{5}{*}{.52} \\
\hline & $\mathrm{m} 6$ & .62 & .38 & & \\
\hline & $\mathrm{m} 7$ & .84 & .70 & & \\
\hline & $\mathrm{m} 8$ & .69 & .47 & & \\
\hline & $\mathrm{m} 81$ & .63 & .39 & & \\
\hline \multirow[t]{4}{*}{$\mathrm{F} 4$} & $\mathrm{~m} 21$ & .84 & .71 & \multirow[t]{4}{*}{.87} & \multirow[t]{4}{*}{.62} \\
\hline & $\mathrm{m} 27$ & .83 & .68 & & \\
\hline & $\mathrm{m} 30$ & .67 & .45 & & \\
\hline & $\mathrm{m} 31$ & .79 & .63 & & \\
\hline \multirow[t]{4}{*}{ F5 } & $\mathrm{m} 10$ & .69 & .48 & \multirow[t]{4}{*}{.85} & \multirow[t]{4}{*}{.60} \\
\hline & $\mathrm{m} 11$ & .52 & .27 & & \\
\hline & $\mathrm{m} 12$ & .91 & .83 & & \\
\hline & $\mathrm{m} 13$ & .90 & .81 & & \\
\hline \multirow[t]{3}{*}{ F6 } & $\mathrm{m} 70$ & .65 & .43 & \multirow[t]{3}{*}{.86} & \multirow[t]{3}{*}{.69} \\
\hline & $\mathrm{m} 82$ & .90 & .81 & & \\
\hline & $\mathrm{m} 83$ & .87 & .76 & & \\
\hline \multirow[t]{4}{*}{ F7 } & $\mathrm{m} 14$ & .64 & .41 & \multirow[t]{4}{*}{.80} & \multirow[t]{4}{*}{.50} \\
\hline & $\mathrm{m} 47$ & .72 & .52 & & \\
\hline & $\mathrm{m} 51$ & .66 & .44 & & \\
\hline & $\mathrm{m} 52$ & .79 & .63 & & \\
\hline \multirow[t]{3}{*}{ F8 } & m59 & .89 & .78 & \multirow[t]{3}{*}{.87} & \multirow[t]{3}{*}{.69} \\
\hline & $\mathrm{m} 60$ & .86 & .75 & & \\
\hline & $\mathrm{m} 68$ & .73 & .53 & & \\
\hline
\end{tabular}

Based on Figure 1, chi-square/df ratio is 3.649, less than 5, GFI and AGFI both are .852 and .822, larger than .8, respectively, and RMSEA is .066, falling in between .05 and .08 . This fact proves the model fit is reasonable. In Table 2, all factor loadings are larger than 
.5 , signifying the relationship between each observed variable and the underlying factor (latent variable) is supported. Also, the CR's and AVE's values are larger than .70 and .50, respectively, signifying the convergent validity is supported.

Torkzadeh et al. [58] argued that if the confidence interval of the paired correlation doesn't include the value of 1 following correlations among latent variables paired, the model's discriminant validity is evidenced. Table 3 shows the result of computing the 95\% confidence interval for the correlations between two latent variables via Bias-corrected percentile method.

Table 3. The Correlations between Two Latent Variables

\begin{tabular}{|c|c|c|c|}
\hline Parameter & Estimate & Lower & Upper \\
\hline F1 <--> F2 & $.372^{* *}$ & .307 & .449 \\
\hline F1 <--> F3 & $.530^{*}$ & .433 & .594 \\
\hline F1 <--> F4 & $.350^{* *}$ & .270 & .438 \\
\hline F1 <--> F5 & $.309^{* *}$ & .208 & .403 \\
\hline F1 <--> F6 & $.687^{*}$ & .589 & .748 \\
\hline F1 <--> F7 & $.723^{*}$ & .632 & .781 \\
\hline F1 <--> F8 & $.598^{*}$ & .517 & .651 \\
\hline F2 <--> F3 & .083 & -.026 & .178 \\
\hline F2 <--> F4 & $.287^{*}$ & .182 & .378 \\
\hline F2 <--> F5 & $.170^{* *}$ & .081 & .247 \\
\hline F2 <--> F6 & $.361^{* *}$ & .282 & .443 \\
\hline F2 <--> F7 & $.476^{*}$ & .385 & .542 \\
\hline F2 <--> F8 & $.531^{* *}$ & .446 & .599 \\
\hline F3 <--> F4 & $.478^{* *}$ & .414 & .546 \\
\hline F3 <--> F5 & $.679 * *$ & .610 & .734 \\
\hline F3 <--> F6 & $.388^{*}$ & .305 & .465 \\
\hline F3 <--> F7 & $.545^{*}$ & .451 & .617 \\
\hline F3 <--> F8 & $.386^{*}$ & .302 & .453 \\
\hline F4 <--> F5 & $.535^{* *}$ & .462 & .603 \\
\hline F4 <--> F6 & $.315^{*}$ & .218 & .382 \\
\hline F4 <--> F7 & $.586^{* *}$ & .488 & .660 \\
\hline F4 <--> F8 & $.455^{*}$ & .365 & .542 \\
\hline F5 <--> F6 & $.213^{*}$ & .119 & .310 \\
\hline F5 <--> F7 & $.471^{* *}$ & .367 & .546 \\
\hline F5 <--> F8 & $.327^{*}$ & .237 & .402 \\
\hline F6 <--> F7 & $.547^{*}$ & .452 & .639 \\
\hline F6 <--> F8 & $.514^{*}$ & .426 & .584 \\
\hline F7 <--> F8 & $.635^{*}$ & .542 & .698 \\
\hline
\end{tabular}

Note: ${ }^{*}$ stands for $\mathrm{p}<.05,{ }^{* *}$ stands for $\mathrm{p}<.01$

Based on Table 3, correlations between two latent variables exit except "F2 v.s. F3", but each value between lower bound and the upper bound does not contain 1, demonstrating discriminant validity is supported.

After item analysis, internal consistency reliability analysis, three-time EFA, and CFA, not only has reliability and validity of the Q-JLMLC proved to be good, but the eight common factors standing for eight types of Japanese learners' motivation for learning Chinese are extracted. According to item description in the eight factors, the eight motivation types are named as follows: 
Type 1: Instrumental motivation. Item descriptions that fall in this category are $\mathrm{m} 4$ "I learn Chinese to find better job opportunities.", m15 "I learn Chinese because fluent Chinese is a symbol of good education and accomplishment.", m38 "I learn Chinese because increasing Chinese proficiency will have financial benefits for me.", m48 "Learning Chinese will give me higher status in my job.", and m49 "I learn Chinese in order to achieve an occupational goal.".

Type 2: Personal orientation. Item descriptions that fall in this category are m40 "I learn Chinese to win a scholarship to a university in Chinese speaking countries.", m54 "Learning Chinese helps me communicate with my children.", m55 "I learn Chinese to keep up with my children.", m57 "I learn Chinese to answer questions asked by my children.", and m79 "I learn Chinese to share a common interest with my spouse.".

Type 3: Identified regulation. Item descriptions that fall in this category are $\mathrm{m} 5$ "I learn Chinese to better myself.", m6 "I learn Chinese to find better education opportunities.", m7 "I learn Chinese to become a better-educated person.", m8 "I learn Chinese to get something meaningful out of life.", and m81 "I learn Chinese because I like learning new things.".

Type 4: Chinese cultural productions. Item descriptions that fall in this category are m21 "I learn Chinese because I am interested in Chinese TV shows.", m27 "I learn Chinese because I am interested in Chinese movies.", m30 "I learn Chinese to be able to read Chinese newspaper and magazines.", and m31 "I learn Chinese because I am interested in Chinese songs.".

Type 5: Integrating into Chinese community. Item descriptions that fall in this category are $\mathrm{m} 10$ "I learn Chinese to make friends with native Chinese speakers." , m11 "I feel bad if I couldn't speak Chinese to my Chinese friends.", m12 "I learn Chinese because I want to learn about Chinese customs.", and m13 "I learn Chinese to know about how Chinese people live.".

Type 6: External regulation. Item descriptions that fall in this category are $\mathrm{m} 70$ "I learn Chinese in order to obtain an academic degree.", m82 "I learn Chinese in order to obtain high scores in examinations.", and m83 "I learn Chinese to pass examinations.".

Type 7: Social responsibility. Item descriptions that fall in this category are $\mathrm{m} 14$ "I learn Chinese to help people who cannot speak Chinese.", m47 "I learn Chinese to let the world know more about my country.", m51 "I learn Chinese because I want to be part of the Chinese resource in my country.", and m52 "I learn Chinese because I can contribute to my country's economic prosperity.".

Type 8: Chinese for academic purposes. Item descriptions that fall in this category are $\mathrm{m} 59$ "I learn Chinese to communicate with international specialists in my own academic field.", m60 "I learn Chinese to comprehend the research literature in my own academic field.", and m68 "I learn Chinese to understand presentations presented in Chinese by international peers in conferences.".

\subsection{The Difference of Motivations to Learn Chinese among the Different Aged Japanese CFL Learners}

Table 4 shows that at least one significant difference in the motivation for learning Chinese among the different aged Japanese learners following one-way ANOVA analysis (Wilk's $\lambda=.606$, MANOVA F=13.79, $\mathrm{p}=.000<.001$ ). 
Table 4. Comparison of the motivation for learning Chinese among differently aged Japanese learners

\begin{tabular}{|c|c|c|c|c|c|c|c|c|c|c|c|c|}
\hline \multirow[t]{2}{*}{ Groups } & \multicolumn{2}{|c|}{$\begin{array}{l}\text { Children } \\
(n=167)\end{array}$} & \multicolumn{2}{|c|}{$\begin{array}{l}\text { Adolescents } \\
(n=126)\end{array}$} & \multicolumn{2}{|c|}{$\begin{array}{l}\text { Traditional } \\
\text { adult learn- } \\
\text { ers } \\
(\mathrm{n}=92)\end{array}$} & \multicolumn{2}{|c|}{$\begin{array}{l}\text { Non-traditional } \\
\text { adult learners } \\
\quad(n=231)\end{array}$} & \multirow[t]{2}{*}{ F test } & \multirow[t]{2}{*}{ Scheffé } & \multirow[t]{2}{*}{$\eta^{2}$} & \multirow[t]{2}{*}{$\begin{array}{c}\text { Observed } \\
\text { Power }\end{array}$} \\
\hline & $\mathbf{M}$ & SD & $\mathbf{M}$ & SD & $\mathbf{M}$ & SD & $\mathbf{M}$ & SD & & & & \\
\hline $\begin{array}{l}\text { Instrumental } \\
\text { motivation }\end{array}$ & 3.37 & 1.17 & 3.21 & 1.12 & 3.50 & .93 & 2.55 & 1.20 & $24.931^{* * *}$ & $\begin{array}{c}\text { Children }>\text { Non-traditional adult learners } \\
\text { Adolescents }>\text { Non-traditional adult } \\
\text { learners } \\
\text { Traditional adult learners }>\text { Non-tradi- } \\
\text { tional adult learners }\end{array}$ & .109 & 1.00 \\
\hline $\begin{array}{c}\text { Personal } \\
\text { orientation }\end{array}$ & 1.82 & 1.08 & 1.69 & .88 & 1.47 & .77 & 1.50 & 1.01 & $4.633^{* *}$ & $\begin{array}{c}\text { Children }>\text { Traditional adult learners } \\
\text { Children }>\text { Non-traditional adult learn- } \\
\text { ers }\end{array}$ & .022 & .892 \\
\hline $\begin{array}{l}\text { Identified } \\
\text { regulation }\end{array}$ & 3.51 & 1.10 & 3.27 & 1.15 & 4.02 & .90 & 3.53 & 1.05 & $8.969^{* * *}$ & $\begin{array}{c}\text { Traditional adult learners }>\text { Children } \\
\text { Traditional adult learners }>\text { Adolescents } \\
\text { Traditional adult learners }>\text { Non-tradi- } \\
\text { tional adult learners }\end{array}$ & .042 & .996 \\
\hline $\begin{array}{c}\text { Chinese } \\
\text { Cultural } \\
\text { productions }\end{array}$ & 2.21 & 1.16 & 2.48 & 1.33 & 2.50 & 1.15 & 2.70 & 1.18 & $5.346^{* *}$ & Non-traditional adult learners $>$ Children & .026 & .933 \\
\hline $\begin{array}{l}\text { Integrating } \\
\text { into Chinese } \\
\text { community }\end{array}$ & 2.86 & 1.17 & 2.68 & 1.18 & 3.70 & 1.00 & 3.37 & 1.11 & $21.273^{* * *}$ & $\begin{array}{c}\text { Traditional adult learners }>\text { Children } \\
\text { Traditional adult learners }>\text { Adolescents } \\
\text { Non-traditional adult learners }>\text { Children } \\
\text { Non-traditional adult learners }>\text { Adoles- } \\
\text { cents }\end{array}$ & .094 & 1.00 \\
\hline $\begin{array}{c}\text { External } \\
\text { regulation }\end{array}$ & 2.97 & 1.41 & 2.94 & 1.41 & 3.34 & 1.12 & 2.01 & 1.22 & $32.814^{* * *}$ & $\begin{array}{c}\text { Children }>\text { Non-traditional adult learners } \\
\text { Adolescents }>\text { Non-traditional adult } \\
\text { learners } \\
\text { Traditional adult learners }>\text { Non-tradi- } \\
\text { tional adult learners } \\
\end{array}$ & .139 & 1.00 \\
\hline $\begin{array}{c}\text { Social } \\
\text { responsibility }\end{array}$ & 2.72 & 1.20 & 2.80 & 1.14 & 3.01 & 1.07 & 2.35 & 1.17 & $9.045^{* * *}$ & Children $>$ Non-traditional adult learners & .042 & .996 \\
\hline
\end{tabular}




\begin{tabular}{cccccccccccc}
\hline & & & & & & & & $\begin{array}{c}\text { Adolescents }>\text { Non-traditional adult } \\
\text { learners } \\
\text { Traditional adult learners }>\text { Non-tradi- } \\
\text { tional adult learners }\end{array}$ \\
\hline $\begin{array}{c}\text { Chinese for } \\
\text { academic } \\
\text { purposes }\end{array}$ & 2.29 & 1.30 & 2.40 & 1.28 & 2.20 & 1.27 & 1.84 & 1.21 & $7.118^{* * *}$ & $\begin{array}{c}\text { Children>Non-traditional adult learners } \\
\text { Adolescents }>\text { Non-traditional adult } \\
\text { learners }\end{array}$ \\
\hline & & & & & & & & & MANOVA F= $13.79^{* * *}$ \\
\hline
\end{tabular}

Note: ${ }^{* *}$ stands for $\mathrm{p}<.01,{ }^{* * *}$ stands for $\mathrm{p}<.001$ MANOVA $\mathrm{F}=13.79^{* * *}$ 
As shown in Table 4, the eight motivation types among the different aged Japanese learners of Chinese, based on the $\mathrm{F}$ values and $\mathrm{p}$ values less than .01, are significantly different following the one-way ANOVA analysis. After Scheffé's method for multiple comparisons, this study revealed that the children', adolescents' and traditional adults' instrumental motivation is significantly higher than that of the non-traditional adults. Also, $\eta 2$ is .109, which means that with age being the independent variable, the effect size is medium (explained variance is $10.9 \%$ ). The observed power is 1.00 , which means the probability of drawing the correct conclusion from a statistically significant result is $100 \%$.

Secondly, this study revealed that the children' personal orientation is significantly higher than the (non-) traditional adult learners' one. Also, $\eta 2$ is .022, which means that with age being the independent variable, the effect size is small (explained variance is $2.2 \%$ ). The observed power is .892 , which means the probability of drawing the correct conclusion from a statistically significant result is $89.2 \%$.

Thirdly, this study revealed that the traditional adults' identified regulation (IR) is significantly higher than that of children', adolescents' and non-traditional adults' one. Also, $\eta 2$ is .042, which means that with age being the independent variable, the effect size is small (explained variance is $4.2 \%$ ). The observed power is .996 , which means the probability of drawing the correct conclusion from a statistically significant result is $99.6 \%$.

Fourthly, this study revealed that the non-traditional adults' motivation for Chinese cultural productions is significantly higher than the children' one. Also, $\eta 2$ is .026, which means that with age being the independent variable, the effect size is small (explained variance is $2.6 \%$ ). The observed power is .933 , which means the probability of drawing the correct conclusion from a statistically significant result is $93.3 \%$.

Fifthly, this study revealed that the (non-)traditional adults' integrative motivation into Chinese communities is significantly higher than the children' and adolescents' one. Also, $\eta 2$ is .094, which means that with age being the independent variable, the effect size is medium (explained variance is $9.4 \%$ ). The observed power is 1.00 , which means the probability of drawing the correct conclusion from a statistically significant result is $100 \%$.

Sixthly, this study showed that the children', adolescents' and traditional adults' ER is significantly higher than that of the non-traditional adults. Also, $\eta 2$ is .139, which means that with age being the independent variable, the effect size closes to large (explained variance is $13.9 \%$ ). The observed power is 1.00 , which means the probability of drawing the correct conclusion from a statistically significant result is $100 \%$.

The same as the ER, this study also found that the children', adolescents' and traditional adults' social responsibility is significantly higher than that of the non-traditional adults. Also, $\eta 2$ is .042, which means that age as independent variable, of which effect size is small (explained variance is $4.2 \%$ ). The observed power is .996 , which means the probability of drawing the correct conclusion from a statistically significant result is $99.6 \%$.

Finally, this study revealed that the children' and adolescents' CAP is significantly higher than the non-traditional adults' CAP. Also, $\eta 2$ is .034 , which means that with age being the independent variable, the effect size is small (explained variance is $3.4 \%$ ). The observed power is .982, which means the probability of drawing the correct conclusion from a statistically significant result is $98.2 \%$.

\section{Discussion}

The main objective of the present study was to provide an effective treatment for sustainable Chinese language learning in Japan with comparing to understand motivations to learn Chinese as s foreign language among differently aged Japanese learners.

The results related to the types of the different aged Japanese learners' motivation for learning Chinese showed that the eight motivation types were shared by Japanese learners. Type 1-Instrumental motivation was extracted a construct from five observed variables $(\mathrm{m} 4$, $\mathrm{m} 15, \mathrm{~m} 38, \mathrm{~m} 48$, and $\mathrm{m} 49$ ) of which meaning was a person is instrumentally motivated to learn a foreign language because of practical reasons, such as bettering jobs, obtaining 
good education and accomplishment, and increasing financial benefits. The instrumental motivation of Japanese learners was consistent with those found in earlier studies [59,60]. Type 2-Personal orientation was also found in previous research. For example, one of learning motivations in adulthood is family togetherness, concerned with bridging generation gaps and improving relationships in families [46]. Learning English to help one's children learn English is one of observed variables in motivation for personal goals [49]. $\mathrm{Xu}$ and Gao [50] defined motivation for individual development as to enhance one's competitiveness and improve one's social status. Personal orientation, such as learning Chinese for oneself and significant others, are defined in this study according to the item descriptions. Type 3-Identified regulation, based on Deci et al. [61], was a more autonomous form of extrinsic motivation than introjected regulation. For Japanese learners, they had identified him/herself with the importance or value of what he/she per-forms. (e.g., learning Chinese for bettering oneself, for better education opportunities, for getting something meaningful, etc.). Type 4-Chinese cultural productions, line with Gardner's integrative motivation [62], was a set of attitudes reflecting openness to target language cultural material, so interests in learning more about Chinese cultural elements, such as movies, songs, TV shows, newspapers and magazines, are found in Japanese learners' motivation for learning Chinese. Type 5-Integrating into Chinese community, as part of integrative motivation, is a wish to know and to be integrated into a Chinese language community, according to Gardner's definition [63]. Type 6-External regulation was a form of extrinsic motivation and the least self-determined. For example, learners might not want to fail the class and were trying to get a good grade on the test [64], so the three items (m70, m82, and m83) reflected Japanese learners' motivation of external regulation while learning Chinese. Type 7-Social responsibility concurred with in Xu \& Gao's finding [50], in which the social responsibility is defined as learning a foreign language to contribute to home country's prosperity, to let the world know more about home country, and to contribute to the mutual understanding among peoples in the world. Type 8-Chinese for academic purposes was extracted a construct from three observed variables (m59, m60, and m68). Not only did $\mathrm{Xu}$ and Gao [50] found that using English to obtain research information is one of Chinese university students' motivation for learning English, but this study also found that learning Chinese for academic purposes is one motivation among the different aged Japanese learners.

Regarding the results related to the difference of motivations to learn Chinese among the different aged Japanese CFL learners, the present study found that the children', adolescents' and traditional adults' instrumental motivation is significantly higher than that of the nontraditional adults. The result is correlated with other studies that demonstrated that the age factor has an important role on motivation during foreign language acquisition. For example, young learners in Belgium are mostly motivated to learn French because it allows them to travel, to expand the boundaries of their social setting and also to increase the chances of finding employment after college, and young learners are a little more motivated than elder ones [65]. Hong and Ganapathy [60] used a qualitative case study via focus group interviews to elicit data from 12 students aged 16 in a secondary school in Penang and found that the students are more instrumentally motivated than integratively motivated in ESL learning. Secondly, the Japanese children' personal orientation significantly higher than that of the Japanese (non-) traditional adult learners was found. The similar results can be found in previous research. For example, Xue and Chen [28] surveyed 140 primary and secondary school students in Chinese schools in Japan, and found nearly $70 \%$ of students were motivated to learn Chinese because of their parents' encouragement, and $20.8 \%$ of them were motivated to learn Chinese for personal study and future jobs. Asmali [66] found parents, teachers, and favorable learning conditions and activities were important factors in determining Turkish pupils' motivation to learn English. Adult learners' motivation is typically self-directed, relevancy-oriented, and learner-ori- 
ented $[67,68]$, but the children found in this study have a stronger personal-oriented motivation to learn Chinese than other learners even though the degree of impact on their personal-oriented motivation is under $39 \%$.

Compared with other age groups (children, adolescents, and non-traditional adult learners), more research focused on exploring Chinese learning motivation of traditional adult learners, signifying those who are full-time undergraduates aged 18-23, do not work or do part-time works, and have few, if any, family responsibilities. Zhang's survey study [69] found 70.9\% Japanese undergraduates learning Chinese because they think it is useful after entering society, and 53.5\% of them are interested in China so they learn Chinese. Kuo's cases studies [70] found three traditional adult learners' motivations to learn Chinese are instrumental, inquisitive, and ideological, and two non-traditional adult learners are motivated integratively and interpersonally to learn Chinese. Tao [37] analyzed 328 Japanese university students' motivation to learn Chinese and found $51.5 \%$ of them took Chinese courses because it is easy to get credits and male undergraduates' motivation is higher than females. The second one is "to increase the opportunity for job promotion in the future", accounting for $43.0 \%$, and the third one is "to travel to China", accounting for $41.8 \%$. Also, the female undergraduates' motivation for travelling to China is higher than males'. Previous research findings are not completely identical to this study, revealing that the traditional adults' identified regulation (IR) is significantly higher than that of children', adolescents' and non-traditional adults' one, but the traditional adults' motivation for bettering themselves is proved again.

Compared with other related research, little research has focused on exploring learning Chinese motivation of non-traditional adult learners even though over half of the population are non-traditional adults [71]. Akçay et al. [72] found 22.61\% Turkish young learners' leading motivation to learn English is to talk to foreigners/tourists visiting their city, followed by entertainment, such as being fond of movies, songs, and computer games (16.67\%). Ferrari [73] interviewed 26 adult learners of Italian aged 25-69 and found the main reasons to enroll in Italian courses are learning about "culture", "art, architecture, history", and attractiveness of Italian, and few reasons are learning Italian for "music and opera", "fashion", and "literature". The above findings are not completely consistent with this study, revealing that the non-traditional adults' motivation for Chinese cultural productions is significantly higher than the children' one, but Hudson [74] found the majority (95\%) of participants wished to learn English to improve their communication with English speakers, and to improve their understanding of the media, i.e. TV, radio and the press. Hudson's finding echoes to that of this study. It proved that, therefore, exploring different subjects and target languages results in different research results.

Integrating into Chinese communities belongs to integrative motivation besides Chinese cultural productions. Hudson [74] gathered 44 adult learners aged from 18to 55 and over via using the online survey 'Survey Gizmo' and found 91\% wanted to learn English to be accepted and respected as members of English speaking society, while, $89 \%$ wished to learn English to make friends from different countries. A further $86 \%$ chose to learn the language to understand the culture and life of the English speaking society, and 82\% needed the language to participate in local activities and events. Arthur and Beaton [75] found the majority of adult foreign language learners associate travel with reasons to learn. Childhood experiences and exposure to another language clearly matter because a surprising number of adults were exposed to aspects of foreign language or culture at one time in their childhood. Although the impact of such exposure on the adults who learn a foreign language for integrating into target community is not found, the present study corroborated that the Japanese (non-)traditional adults' integrative motivation into Chinese communities is significantly higher than that of the Japanese children and adolescents.

With respect to the external regulation (ER), Noels et al. [76] analyzed the motivational orientations to learn a second language of the 159 students whose age went from 18 
to 50 and registered in English psychology classes at a French-English bilingual university, and found that "external regulation" $(\mathrm{M}=3.94, \mathrm{SD}=1.45)$, second to "IR", influences the students to learn a second language. Also, the ER had no correlations with the criterion variables (Freedom of Choice and Perceived Competence), but IR was strongly correlated with the criterion variables. Aydogan [77] found the ER is one extrinsic motivation that influences 300 students, aged 17-23 and whose English levels were quite good, to learn English by using exploratory factor analysis. This finding of the children', adolescents' and traditional adults' ER significantly higher than that of the non-traditional adults was similar to the previous research results, and the present study analyzed the differences among the different aged Japanese learners' ER motivation to fill in the knowledge gap.

As for social responsibility, Wentzel [78] reported teacher support was a positive predictor of both types of interest and of social responsibility goal pursuit. Gao et al. [79] used an exploratory factor analysis to study 2,278 undergraduates from 30 universities in 29 regions of China, and found the social responsibility is not only one of the undergraduates' motivation to learn English, but the English majors whose scores are also higher on intrinsic interest, social responsibility, individual development, and information medium than that of the non-English majors. Although the surveyed subjects and target languages in this study differ from the previous studies, they found an echo in each other.

In respect to learning a foreign language for academic the number of non-native students studying in English-medium universities has increased over the past decade and the issues in English for academic purposes (EAP) have lasted over 35 years. However, no one research-based volume has investigated the theoretical issues and pedagogical concerns of the area [80]. Not only does this problem exist in EAP but also in Chinese for academic purposes (CAP). With population of non-native Chinese speakers studying in China and Taiwan for obtaining academic degrees increasing in recent years, CAP courses are offered [81]. Nevertheless, no research is conducted in CAP except EAP. Xu and Gao [50] found as far as over 1300 students from five Chinese universities are concerned, the EAP is one of motivation to learn English, but no correlation was found between the EAP motivation and their identities through a questionnaire in a four-year longitudinal study. Another research indicated that $70 \%$ of the Master of Arts students have never taken any academic writing course before and want a new course which provides them with generic features for writing a research article/thesis [82]. To fill the knowledge gap of little research focusing on CAP motivation of learners under 18 years old, the present study found that the Japanese children' and adolescents' CAP is significantly higher than the Japanese non-traditional adults' CAP.

\section{Conclusions}

A lot of research on motivation to learn a foreign language has been conducted for many years, and are still kept exploring. This academic phenomenon displays the issue has been of high importance. This is because that understanding learners' motivation to learn a foreign language is beneficial for a teacher not only to select an appropriate textbook, but also to use applicable teaching strategies to increase the learners' motivation.

Each Japanese learner studying Chinese language is an independent individual, and their motivation to participate in Chinese language programs is multiple and complicated. The fact has been proven not only by previous research but also by this study. This study categorized Japanese learners' eight types of motivation, including 1) "instrumental motivation", 2) "personal orientation", 3) "identified regulation", 4) "Chinese cultural productions", 5) "integrating into Chinese community", 6) "external regulation", 7) "social responsibility", and 8) Chinese for academic purposes, via reliable and valid evidence. This study also reveals that the instrumental motivation in Japanese children, adolescents, and traditional adult learners are significantly higher than that in non-traditional adult learners. Japanese children are significantly higher in the personal-oriented motivation than traditional and non-traditional adult learners respectively. However, traditional 
adult learners are significantly higher in the identified regulation than children, adolescents, and non-traditional adult learners; non-traditional adult learners are significantly higher in Chinese cultural productions than children, and traditional and non-traditional adult learners are significantly higher in integrating into Chinese communities than children and adolescents respectively. Children, adolescents, and traditional adult learners are respectively significantly higher in the external regulation and social responsibility than non-traditional adult learners. Finally, children and adolescents are significantly higher in Chinese for academic purposes than non-traditional adult learners, but no significant difference exits in two groups of aged adult learners.

Findings from various studies on motivation to learn Chinese language or other foreign languages are not only diverse but also changing [75], so perfect and universal teaching principles virtually do not exist. This study contributes the understanding of motivation types and differences among the four aged Japanese learners to TCSOL teachers and future research. TCSOL teachers are advised to pay attention to each learner's motivation, to deliberate how to effectively use these motivational factors in teaching the four different aged Japanese learners Chinese language, so that their motivation can be maintained. Moreover, while extrinsic motivation has a negative predictive effect on students' academic achievement, intrinsic motivation has positive predictive effects [83]. So it is important for future research to explore how differently aged Japanese learners can have a higher intrinsic motivation and use it as a main drive to learn Chinese as a lifelong business.

Author Contributions: The author conceived and designed the study, acquired and analyzed the data, drafted and wrote the manuscript, and submitted it to Sustainability for reviewing and publishing. The author has read and agreed to the published version of the manuscript.

Funding: This research was funded by Taiwan Ministry of Science and Technology, grant number 107-2410-H-142-008-.

Acknowledgments: The author would like to thank all participants involving in this study.

Conflicts of Interest: The author declare no conflict of interest. 


\title{
Appendix A
}

\author{
日籍華語文學習者動機問卷量表 \\ 日本人向けの中国語学び動機付け調査票 \\ Questionnaire for Japanese Learners' Motivation toward Learning Chinese" (Q-JLMLC)
}

一、日籍華語文學習者動機量表 日本人向けの中国語学び動機付けスケール

Scale for Japanese learners' motivation toward learning Chinese (JLMTLC)

\begin{tabular}{|c|c|c|c|c|c|}
\hline 題目 項目 Items & \multicolumn{5}{|c|}{$\begin{array}{l}\text { 影響程度 影響の程度 } \\
\text { Degree of impact }\end{array}$} \\
\hline $\begin{array}{l}\text { 1.我學華語文是為了實踐「活到老，學到老」這句話。 } \\
\text { 「生きて行く限り学び続ける」という諺を実践するために } \\
\text { 、中国語を学んでいます。 } \\
\text { I learn Chinese to live up to a saying which goes, “Never } \\
\text { too late to learn”. }\end{array}$ & $\begin{array}{l}\text { Above } \\
80 \% \\
\text { 以上 } \\
\square\end{array}$ & $60 \sim 79 \%$ & $40 \sim 59 \%$ & $20 \sim 39 \%$ & $\begin{array}{l}\text { Under } \\
19 \% \\
\text { 以下 } \\
\square\end{array}$ \\
\hline $\begin{array}{l}\text { 2.我學華語文是為了寫和華人同儕相同程度的華語文研究論 } \\
\text { 文。 } \\
\text { ネイティブと同様のレベルで中国語の研究論文を書くため } \\
\text { に、中国語を学んでいます。 } \\
\text { I learn Chinese to write Chinese research papers compara- } \\
\text { ble to those written by native Chinese speaking peers. }\end{array}$ & $\begin{array}{l}\text { Above } \\
80 \% \\
\text { 以上 } \\
\square\end{array}$ & $60 \sim 79 \%$ & $40 \sim 59 \%$ & $20 \sim 39 \%$ & $\begin{array}{l}\text { Under } \\
19 \% \\
\text { 以下 } \\
\square\end{array}$ \\
\hline $\begin{array}{l}\text { 3.我學華語文是為了找到工作而做的準備。 } \\
\text { よい仕事を見つけるための準備として語を学んでい } \\
\text { ます。 } \\
\text { Learning Chinese is a preparation for getting a job. }\end{array}$ & $\begin{array}{l}\text { Above } \\
80 \% \\
\text { 以上 } \\
\square\end{array}$ & $60 \sim 79 \%$ & $40 \sim 59 \%$ & $20 \sim 39 \%$ & $\begin{array}{l}\text { Under } \\
19 \% \\
\text { 以下 } \\
\square\end{array}$ \\
\hline $\begin{array}{l}\text { 4.我學華語文是為了找更好的工作。 } \\
\text { より良い仕事のチャンスを掴むために、中国語を学んでい } \\
\text { ます。 } \\
\text { I learn Chinese to find better job opportunities. }\end{array}$ & $\begin{array}{l}\text { Above } \\
80 \% \\
\text { 以上 } \\
\square\end{array}$ & $60 \sim 79 \%$ & $40 \sim 59 \%$ & $20 \sim 39 \%$ & $\begin{array}{l}\text { Under } \\
19 \% \\
\text { 以下 } \\
\square\end{array}$ \\
\hline $\begin{array}{l}\text { 5.我學華語文是為了讓自己更好。 } \\
\text { より良い自分を生み出すために、中国語を学んでいます。 } \\
\text { I learn Chinese to better myself. }\end{array}$ & $\begin{array}{l}\text { Above } \\
80 \% \\
\text { 以上 } \\
\square\end{array}$ & $60 \sim 79 \%$ & $40 \sim 59 \%$ & $20 \sim 39 \%$ & $\begin{array}{l}\text { Under } \\
19 \% \\
\text { 以下 } \\
\square\end{array}$ \\
\hline $\begin{array}{l}\text { 6.我學華語文是為了找更好的教育機會。 } \\
\text { より良い学習のチャンスを掴むために、中国語を学んでい } \\
\text { ます。 } \\
\text { I learn Chinese to find better education opportunities. }\end{array}$ & $\begin{array}{l}\text { Above } \\
80 \% \\
\text { 以上 } \\
\square\end{array}$ & $60 \sim 79 \%$ & $40 \sim 59 \%$ & $20 \sim 39 \%$ & $\begin{array}{l}\text { Under } \\
19 \% \\
\text { 以下 } \\
\square\end{array}$ \\
\hline $\begin{array}{l}\text { 7.我學華語文是為了成為更有教育素養的人。 } \\
\text { より国い誟養を身に着けるために、中国語をんでいます } \\
\text { 。 } \\
\text { I learn Chinese to become a better-educated person. }\end{array}$ & $\begin{array}{l}\text { Above } \\
80 \% \\
\text { 以上 } \\
\square\end{array}$ & $60 \sim 79 \%$ & $40 \sim 59 \%$ & $20 \sim 39 \%$ & $\begin{array}{l}\text { Under } \\
19 \% \\
\text { 以下 } \\
\square\end{array}$ \\
\hline 8. 我學華語文是為了從生活中獲得意義。 & $\begin{array}{c}\text { Above } \\
80 \%\end{array}$ & $60 \sim 79 \%$ & $40 \sim 59 \%$ & $20 \sim 39 \%$ & $\begin{array}{c}\text { Under } \\
19 \%\end{array}$ \\
\hline
\end{tabular}




\begin{tabular}{|c|c|c|c|c|c|}
\hline $\begin{array}{l}\text { 人生におけるなにがしかの意義を得るために、中国語を学 } \\
\text { んでいます。 } \\
\text { I learn Chinese to get something meaningful out of life. }\end{array}$ & $\begin{array}{c}\text { 以上 } \\
\square\end{array}$ & $\square$ & $\square$ & $\square$ & $\begin{array}{c}\text { 以下 } \\
\square\end{array}$ \\
\hline $\begin{array}{l}\text { 9.因為我對華語文學作品有興趣，所以我學華語文。 } \\
\text { 中国の文学に興味があるので、中国語を学んでいます。 } \\
\text { I learn Chinese because I am interested in Chinese litera- } \\
\text { ture. }\end{array}$ & $\begin{array}{l}\text { Above } \\
80 \% \\
\text { 以上 } \\
\square\end{array}$ & $60 \sim 79 \%$ & $40 \sim 59 \%$ & $20 \sim 39 \%$ & $\begin{array}{l}\text { Under } \\
19 \% \\
\text { 以下 } \\
\square\end{array}$ \\
\hline $\begin{array}{l}\text { 10.我學華語文是為了和華人交朋友。 } \\
\text { 中国人と友達になるために、中国語を学んでいます。 } \\
\text { I learn Chinese to make friends with native Chinese speak- } \\
\text { ers. }\end{array}$ & $\begin{array}{l}\text { Above } \\
80 \% \\
\text { 以上 } \\
\square\end{array}$ & $\begin{array}{l}60 \sim 79 \% \\
\square\end{array}$ & $40 \sim 59 \%$ & $20 \sim 39 \%$ & $\begin{array}{l}\text { Under } \\
19 \% \\
\text { 以下 } \\
\square\end{array}$ \\
\hline $\begin{array}{l}\text { 11.如果不能跟華人朋友說華語文, 我會覺得不開心。 } \\
\text { 中国人の友達と中国語で話せないと、落ち込んだり悔しか } \\
\text { つたりします。 } \\
\text { I feel bad if I couldn't speak Chinese to my Chinese friends. }\end{array}$ & $\begin{array}{l}\text { Above } \\
80 \% \\
\text { 以上 } \\
\square\end{array}$ & $60 \sim 79 \%$ & $40 \sim 59 \%$ & $20 \sim 39 \%$ & $\begin{array}{l}\text { Under } \\
19 \% \\
\text { 以下 } \\
\square\end{array}$ \\
\hline $\begin{array}{l}\text { 12.因為我想知道華人的風俗習慣, 所以我學華語文。 } \\
\text { 中国人の風習や習慣について知りたいので、中国語を学ん } \\
\text { でいます。 } \\
\text { I learn Chinese because I want to learn about Chinese cus- } \\
\text { toms. }\end{array}$ & $\begin{array}{l}\text { Above } \\
80 \% \\
\text { 以上 } \\
\square\end{array}$ & $60 \sim 79 \%$ & $40 \sim 59 \%$ & $20 \sim 39 \%$ & $\begin{array}{l}\text { Under } \\
19 \% \\
\text { 以下 } \\
\square\end{array}$ \\
\hline $\begin{array}{l}\text { 13.我學華語文是為了瞭解華人的生活方式。 } \\
\text { 中国人の暮らしを理解するために、中国語を学んでいます } \\
\text { 。 } \\
\text { I learn Chinese to know about how Chinese people live. }\end{array}$ & $\begin{array}{l}\text { Above } \\
80 \% \\
\text { 以上 } \\
\square\end{array}$ & $60 \sim 79 \%$ & $40 \sim 59 \%$ & $20 \sim 39 \%$ & $\begin{array}{l}\text { Under } \\
19 \% \\
\text { 以下 } \\
\square\end{array}$ \\
\hline $\begin{array}{l}\text { 14.我學華語文是為了要幫助不會說華語文的人。 } \\
\text { 中国語ができない人を助けるために、中国語を学んでいま } \\
\text { す。 } \\
\text { I learn Chinese to help people who cannot speak Chinese. }\end{array}$ & $\begin{array}{l}\text { Above } \\
80 \% \\
\text { 以上 } \\
\square\end{array}$ & $60 \sim 79 \%$ & $40 \sim 59 \%$ & $20 \sim 39 \%$ & $\begin{array}{l}\text { Under } \\
19 \% \\
\text { 以下 } \\
\square\end{array}$ \\
\hline $\begin{array}{l}\text { 15.因為會流利的華語文是受好教育和有成就的象徵, 所以 } \\
\text { 我學華語文。 } \\
\text { 中国語が流暢に話せることは、優れた教育を受け、成果を } \\
\text { 収めた証となるので、中国語を学んでいます。 } \\
\text { I learn Chinese because fluent Chinese is a symbol of good } \\
\text { education and accomplishment. }\end{array}$ & $\begin{array}{l}\text { Above } \\
80 \% \\
\text { 以上 } \\
\square\end{array}$ & $60 \sim 79 \%$ & $40 \sim 59 \%$ & $20 \sim 39 \%$ & $\begin{array}{l}\text { Under } \\
19 \% \\
\text { 以下 } \\
\square\end{array}$ \\
\hline $\begin{array}{l}\text { 16.因為我在華語文課可以認識新朋友，所以我學華語文。 } \\
\text { 中国語クラスの中で新しい友達を作ることができるので、 } \\
\text { 中国語を学んでいます。 } \\
\text { I learn Chinese because I can meet new people and make } \\
\text { friends in the Chinese class. }\end{array}$ & $\begin{array}{c}\text { Above } \\
80 \% \\
\text { 以上 } \\
\square\end{array}$ & $60 \sim 79 \%$ & $40 \sim 59 \%$ & $20 \sim 39 \%$ & $\begin{array}{c}\text { Under } \\
19 \% \\
\text { 以下 } \\
\square\end{array}$ \\
\hline $\begin{array}{l}\text { 17.因為我喜歡用華語文來處理難題，所以我學習華語文。 } \\
\text { 中国語で難しい問題に対処することが好きなので、中国語 } \\
\text { を学んでいます。 } \\
\text { I learn Chinese because I like using Chinese to deal with } \\
\text { difficulties. }\end{array}$ & $\begin{array}{c}\text { Above } \\
80 \% \\
\text { 以上 } \\
\square\end{array}$ & $60 \sim 79 \%$ & $40 \sim 59 \%$ & $20 \sim 39 \%$ & $\begin{array}{c}\text { Under } \\
19 \% \\
\text { 以下 } \\
\square\end{array}$ \\
\hline 18.因為中日文都有漢字，所以我學華語文。 & Above & $60 \sim 79 \%$ & $40 \sim 59 \%$ & $20 \sim 39 \%$ & Under \\
\hline
\end{tabular}




\begin{tabular}{|c|c|c|c|c|c|}
\hline $\begin{array}{l}\text { 中国語と日本語はどちらも漢字があるので、中国語を学ん } \\
\text { でいます。 } \\
\text { I learn Chinese because there are Chinese characters in Chi- } \\
\text { nese and Japanese. }\end{array}$ & $\begin{array}{l}80 \% \\
\text { 以上 } \\
\square\end{array}$ & $\square$ & $\square$ & $\square$ & $\begin{array}{l}19 \% \\
\text { 以下 } \\
\square\end{array}$ \\
\hline $\begin{array}{l}\text { 19.我學華語文的目標是能跟母語者說得一樣好。 } \\
\text { 中国語ネイティブの人と同じくらい中国語が上手になるた } \\
\text { めに、中国語を学んでいます。 } \\
\text { I learn Chinese to make myself speak Chinese as well as na- } \\
\text { tive Chinese speakers do. }\end{array}$ & $\begin{array}{l}\text { Above } \\
80 \% \\
\text { 以上 } \\
\square\end{array}$ & $60 \sim 79 \%$ & $40 \sim 59 \%$ & $20 \sim 39 \%$ & $\begin{array}{l}\text { Under } \\
19 \% \\
\text { 以下 } \\
\square\end{array}$ \\
\hline $\begin{array}{l}\text { 20.因為我對華語文課程有興趣, 所以我學華語文。 } \\
\text { 中国語のカリキュラムに興味があるので、中国語を学んで } \\
\text { います。 } \\
\text { I learn Chinese because I am interested in Chinese courses. }\end{array}$ & $\begin{array}{l}\text { Above } \\
80 \% \\
\text { 以上 } \\
\square\end{array}$ & $60 \sim 79 \%$ & $40 \sim 59 \%$ & $20 \sim 39 \%$ & $\begin{array}{l}\text { Under } \\
19 \% \\
\text { 以下 } \\
\square\end{array}$ \\
\hline $\begin{array}{l}\text { 21.因為我對華人電視節目有興趣, 所以我學華語文。 } \\
\text { 中国語のテレビ番組に興味があるので、中国語を学んでい } \\
\text { ます。 } \\
\text { I learn Chinese because I am interested in Chinese TV } \\
\text { shows. }\end{array}$ & $\begin{array}{l}\text { Above } \\
80 \% \\
\text { 以上 } \\
\square\end{array}$ & $60 \sim 79 \%$ & $40 \sim 59 \%$ & $20 \sim 39 \%$ & $\begin{array}{l}\text { Under } \\
19 \% \\
\text { 以下 } \\
\square\end{array}$ \\
\hline $\begin{array}{l}\text { 22.因為我想成為一位好的華語文教師, 所以我學華語文。 } \\
\text { いい中国語の先生になりたいので、中国語を学んでいます } \\
\text { 。 } \\
\text { I learn Chinese because I want to be a good Chinese teacher. }\end{array}$ & $\begin{array}{l}\text { Above } \\
80 \% \\
\text { 以上 } \\
\square\end{array}$ & $60 \sim 79 \%$ & $40 \sim 59 \%$ & $20 \sim 39 \%$ & $\begin{array}{l}\text { Under } \\
19 \% \\
\text { 以下 } \\
\square\end{array}$ \\
\hline $\begin{array}{l}\text { 23.因為我的華語文老師很好，所以我學華語文。 } \\
\text { 中国語の先生は人柄に惹かれて、私は中国語を学んでいま } \\
\text { す。 } \\
\text { I learn Chinese because my Chinese teacher(s) is (are) good. }\end{array}$ & $\begin{array}{l}\text { Above } \\
80 \% \\
\text { 以上 } \\
\square\end{array}$ & $60 \sim 79 \%$ & $40 \sim 59 \%$ & $20 \sim 39 \%$ & $\begin{array}{l}\text { Under } \\
19 \% \\
\text { 以下 } \\
\square\end{array}$ \\
\hline $\begin{array}{l}\text { 24.我學華語文是為了滿足對華語文知識的探究。 } \\
\text { 中国語の知識を深めていきたいために、中国語を学んでい } \\
\text { ます。 } \\
\text { I learn Chinese to quench my thirst for Chinese knowledge. }\end{array}$ & $\begin{array}{l}\text { Above } \\
80 \% \\
\text { 以上 } \\
\square\end{array}$ & $60 \sim 79 \%$ & $40 \sim 59 \%$ & $20 \sim 39 \%$ & $\begin{array}{l}\text { Under } \\
19 \% \\
\text { 以下 } \\
\square\end{array}$ \\
\hline $\begin{array}{l}\text { 25.我知道學華語文是重要的，但我卻無法樂在其中。 } \\
\text { 中国語の勉強は大事だと理解してはいまますが、勉強は楽し } \\
\text { くありません。 } \\
\text { I know that learning Chinese is important for me, but I do } \\
\text { not enjoy learning it. }\end{array}$ & $\begin{array}{l}\text { Above } \\
80 \% \\
\text { 以上 } \\
\square\end{array}$ & $60 \sim 79 \%$ & $40 \sim 59 \%$ & $20 \sim 39 \%$ & $\begin{array}{l}\text { Under } \\
19 \% \\
\text { 以下 } \\
\square\end{array}$ \\
\hline $\begin{array}{l}\text { 26.我學華語文是因為學習華語文很愉快。 } \\
\text { 中国語の勉強は楽しいので、中国語を学んでいます。 } \\
\text { I learn Chinese because learning Chinese is enjoyable. }\end{array}$ & $\begin{array}{l}\text { Above } \\
80 \% \\
\text { 以上 } \\
\square\end{array}$ & $60 \sim 79 \%$ & $40 \sim 59 \%$ & $20 \sim 39 \%$ & $\begin{array}{c}\text { Under } \\
19 \% \\
\text { 以下 } \\
\square\end{array}$ \\
\hline $\begin{array}{l}\text { 27.因為我對華人電影有興趣，所以我學華語文。 } \\
\text { 中国語の映画に興味があるので、中国語を学んでいます。 } \\
\text { I learn Chinese because I am interested in Chinese movies. }\end{array}$ & $\begin{array}{c}\text { Above } \\
80 \% \\
\text { 以上 } \\
\square\end{array}$ & $60 \sim 79 \%$ & $40 \sim 59 \%$ & $20 \sim 39 \%$ & $\begin{array}{c}\text { Under } \\
19 \% \\
\text { 以下 } \\
\square\end{array}$ \\
\hline 28.如果我在華語文課表現不好, 我會覺得不舒服。 & Above & $60 \sim 79 \%$ & $40 \sim 59 \%$ & $20 \sim 39 \%$ & Under \\
\hline
\end{tabular}




\begin{tabular}{|c|c|c|c|c|c|}
\hline $\begin{array}{l}\text { 中国語の授業で上手に発言できないと、落ち込んだり悔し } \\
\text { かつたりします。 } \\
\text { I feel bad if I couldn't perform well in Chinese classes. }\end{array}$ & $\begin{array}{l}80 \% \\
\text { 以上 } \\
\square\end{array}$ & $\square$ & $\square$ & $\square$ & $\begin{array}{l}19 \% \\
\text { 以下 } \\
\square\end{array}$ \\
\hline $\begin{array}{l}\text { 29.因為華語文課是一門營養學分, 所以我學華語文。 } \\
\text { 中国語の授業の単位は取得しやすいので、中国語を学んで } \\
\text { います。 } \\
\text { I learn Chinese because it is easy to get credits in the Chi- } \\
\text { nese class. }\end{array}$ & $\begin{array}{c}\text { Above } \\
80 \% \\
\text { 以上 } \\
\square\end{array}$ & $60 \sim 79 \%$ & $40 \sim 59 \%$ & $20 \sim 39 \%$ & $\begin{array}{c}\text { Under } \\
19 \% \\
\text { 以下 } \\
\square\end{array}$ \\
\hline $\begin{array}{l}\text { 30.我學華語文是為了讀懂華語文報章雜誌。 } \\
\text { 中国語の新聞と杂倠誌を読むために、中国語を学んでいます } \\
\text { 。 } \\
\text { I learn Chinese to be able to read Chinese newspaper and } \\
\text { magazines. }\end{array}$ & $\begin{array}{c}\text { Above } \\
80 \% \\
\text { 以上 } \\
\square\end{array}$ & $60 \sim 79 \%$ & $40 \sim 59 \%$ & $20 \sim 39 \%$ & $\begin{array}{c}\text { Under } \\
19 \% \\
\text { 以下 } \\
\square\end{array}$ \\
\hline $\begin{array}{l}\text { 31.因為我對華語文歌曲有興趣，所以我學華語文。 } \\
\text { 中国語の歌に興味があるので、中国語を学んでいます。 } \\
\text { I learn Chinese because I am interested in Chinese songs. }\end{array}$ & $\begin{array}{c}\text { Above } \\
80 \% \\
\text { 以上 } \\
\square\end{array}$ & $60 \sim 79 \%$ & $40 \sim 59 \%$ & $20 \sim 39 \%$ & $\begin{array}{c}\text { Under } \\
19 \% \\
\text { 以下 } \\
\square\end{array}$ \\
\hline $\begin{array}{l}\text { 32.當我弄懂華語文的難點時, 我感覺很好, 所以我學華語 } \\
\text { 文。 } \\
\text { 中国語の難しいところを理解できると嬉しいので、中国語 } \\
\text { を学んでいます。 } \\
\text { I learn Chinese because I feel good when I resolve the diffi- } \\
\text { culties. }\end{array}$ & $\begin{array}{c}\text { Above } \\
80 \% \\
\text { 以上 } \\
\square\end{array}$ & $60 \sim 79 \%$ & $40 \sim 59 \%$ & $20 \sim 39 \%$ & $\begin{array}{c}\text { Under } \\
19 \% \\
\text { 以下 } \\
\square\end{array}$ \\
\hline $\begin{array}{l}\text { 33.因為學華語文比學英文或其他外語更容易, 所以我學華 } \\
\text { 語文。 } \\
\text { 中国語は英語や他の外国語より勉強しやすいので、中国語 } \\
\text { を学んでいます。 } \\
\text { I learn Chinese because learning Chinese is easier than } \\
\text { learning English or other foreign languages. }\end{array}$ & $\begin{array}{c}\text { Above } \\
80 \% \\
\text { 以上 } \\
\square\end{array}$ & $60 \sim 79 \%$ & $40 \sim 59 \%$ & $20 \sim 39 \%$ & $\begin{array}{c}\text { Under } \\
19 \% \\
\text { 以下 } \\
\square\end{array}$ \\
\hline $\begin{array}{l}\text { 34.華語文可以幫助我辦好事情, 我感覺很好, 所以我學華 } \\
\text { 語文。 } \\
\text { 中国語を使って物事が上手くいくと嬉しいので、中国語を } \\
\text { 学んでいます。 } \\
\text { I learn Chinese because I feel good when I do things well in } \\
\text { Chinese. }\end{array}$ & $\begin{array}{c}\text { Above } \\
80 \% \\
\text { 以上 } \\
\square\end{array}$ & $60 \sim 79 \%$ & $40 \sim 59 \%$ & $20 \sim 39 \%$ & $\begin{array}{c}\text { Under } \\
19 \% \\
\text { 以下 } \\
\square\end{array}$ \\
\hline $\begin{array}{l}\text { 35.我學華語文是因為我喜歡華語文課的同學。 } \\
\text { 中国語を学ぶとき、中国語クラスのクラスメートがよいか } \\
\text { どうかに影響されます。 } \\
\text { I learn Chinese because I like my fellow students in the Chi- } \\
\text { nese class. }\end{array}$ & $\begin{array}{c}\text { Above } \\
80 \% \\
\text { 以上 } \\
\square\end{array}$ & $60 \sim 79 \%$ & $40 \sim 59 \%$ & $20 \sim 39 \%$ & $\begin{array}{c}\text { Under } \\
19 \% \\
\text { 以下 } \\
\square\end{array}$ \\
\hline $\begin{array}{l}\text { 36.我學華語文是因為華語文教科書的質量很好。 } \\
\text { 中国語を学習状況、中国語の教科書の質に影響されます。 } \\
\text { I learn Chinese because my Chinese textbooks are good. }\end{array}$ & $\begin{array}{c}\text { Above } \\
80 \% \\
\text { 以上 } \\
\square\end{array}$ & $60 \sim 79 \%$ & $40 \sim 59 \%$ & $20 \sim 39 \%$ & $\begin{array}{c}\text { Under } \\
19 \% \\
\text { 以下 } \\
\square\end{array}$ \\
\hline $\begin{array}{l}\text { 37.我學華語文是為了能跟上華語文說得流利的人。 } \\
\text { 中国語を流暢に話せる人にことを目標に、中国語を学んで } \\
\text { います。 }\end{array}$ & $\begin{array}{l}\text { Above } \\
80 \% \\
\text { 以上 }\end{array}$ & $60 \sim 79 \%$ & $40 \sim 59 \%$ & $20 \sim 39 \%$ & $\begin{array}{l}\text { Under } \\
19 \% \\
\text { 以下 }\end{array}$ \\
\hline
\end{tabular}




\begin{tabular}{|c|c|c|c|c|c|}
\hline $\begin{array}{l}\text { I learn Chinese to keep up with others who speak Chinese } \\
\text { fluently. }\end{array}$ & $\square$ & $\square$ & $\square$ & $\square$ & $\square$ \\
\hline $\begin{array}{l}\text { 38.因為提升華語文能力有正面的經濟效益, 所以我學華語 } \\
\text { 文。 } \\
\text { 中国語能力を伸ばすことが、金銭的な利益に繋がるので、 } \\
\text { 中国語を学んでいます。 } \\
\text { I learn Chinese because increasing Chinese proficiency will } \\
\text { have financial benefits for me. }\end{array}$ & $\begin{array}{l}\text { Above } \\
80 \% \\
\text { 以上 } \\
\square\end{array}$ & $60 \sim 79 \%$ & $40 \sim 59 \%$ & $20 \sim 39 \%$ & $\begin{array}{l}\text { Under } \\
19 \% \\
\text { 以下 } \\
\square\end{array}$ \\
\hline $\begin{array}{l}\text { 39.我學華語文是為了通過華語文能力測驗。 } \\
\text { 中国語能力試験に合格するために、中国語を学んでいます } \\
\text { 。 } \\
\text { I learn Chinese in order to pass a Chinese Band Test. }\end{array}$ & $\begin{array}{l}\text { Above } \\
80 \% \\
\text { 以上 } \\
\square\end{array}$ & $60 \sim 79 \%$ & $40 \sim 59 \%$ & $20 \sim 39 \%$ & $\begin{array}{l}\text { Under } \\
19 \% \\
\text { 以下 } \\
\square\end{array}$ \\
\hline $\begin{array}{l}\text { 40.我學華語文是為了取得華人國家的大學獎學金。 } \\
\text { 中国語圏の大学で奨学金を取得するために、中国語を学ん } \\
\text { でいます。 } \\
\text { I learn Chinese to win a scholarship to a university in Chi- } \\
\text { nese speaking countries. }\end{array}$ & $\begin{array}{l}\text { Above } \\
80 \% \\
\text { 以上 } \\
\square\end{array}$ & $60 \sim 79 \%$ & $40 \sim 59 \%$ & $20 \sim 39 \%$ & $\begin{array}{l}\text { Under } \\
19 \% \\
\text { 以下 } \\
\square\end{array}$ \\
\hline $\begin{array}{l}\text { 41.學華語文對我到華人國家旅遊是有幫助的。 } \\
\text { 中国語圈の国へ旅行する時に便利なので、中国語を学んで } \\
\text { います。 } \\
\text { Learning Chinese is useful when I travel in Chinese-speak- } \\
\text { ing countries. }\end{array}$ & $\begin{array}{l}\text { Above } \\
80 \% \\
\text { 以上 } \\
\square\end{array}$ & $60 \sim 79 \%$ & $40 \sim 59 \%$ & $20 \sim 39 \%$ & $\begin{array}{l}\text { Under } \\
19 \% \\
\text { 以下 } \\
\square\end{array}$ \\
\hline $\begin{array}{l}\text { 42.我學華語文是為了要移民到華人國家。 } \\
\text { 中国語巻の国へ移民するために、中国語を学んでいます。 } \\
\text { I learn Chinese in order to emigrate to Chinese-speaking } \\
\text { countries. }\end{array}$ & $\begin{array}{l}\text { Above } \\
80 \% \\
\text { 以上 } \\
\square\end{array}$ & $60 \sim 79 \%$ & $40 \sim 59 \%$ & $20 \sim 39 \%$ & $\begin{array}{l}\text { Under } \\
19 \% \\
\text { 以下 } \\
\square\end{array}$ \\
\hline $\begin{array}{l}\text { 43.因為我對華人文化有興趣，所以我學華語文。 } \\
\text { 中華艾化に興味があるので、中国語を学んでいます。 } \\
\text { I learn Chinese because I am interested in Chinese cultures. }\end{array}$ & $\begin{array}{l}\text { Above } \\
80 \% \\
\text { 以上 } \\
\square\end{array}$ & $60 \sim 79 \%$ & $40 \sim 59 \%$ & $20 \sim 39 \%$ & $\begin{array}{l}\text { Under } \\
19 \% \\
\text { 以下 } \\
\square\end{array}$ \\
\hline $\begin{array}{l}\text { 44.因為我是華裔，所以我學華語文。 } \\
\text { 中華系日本人なので、中国語を学んでいます。 } \\
\text { I learn Chinese because I am a Japanese-born Chinese. }\end{array}$ & $\begin{array}{l}\text { Above } \\
80 \% \\
\text { 以上 } \\
\square\end{array}$ & $60 \sim 79 \%$ & $40 \sim 59 \%$ & $20 \sim 39 \%$ & $\begin{array}{l}\text { Under } \\
19 \% \\
\text { 以下 } \\
\square\end{array}$ \\
\hline $\begin{array}{l}\text { 45.我學華語文是為了克服日常生活中的挫折。 } \\
\text { 日常生活の不満や失敗を克服するために、中国語を学んで } \\
\text { います。 } \\
\text { I learn Chinese to overcome the frustration in daily life. }\end{array}$ & $\begin{array}{l}\text { Above } \\
80 \% \\
\text { 以上 } \\
\square\end{array}$ & $60 \sim 79 \%$ & $40 \sim 59 \%$ & $20 \sim 39 \%$ & $\begin{array}{l}\text { Under } \\
19 \% \\
\text { 以下 } \\
\square\end{array}$ \\
\hline $\begin{array}{l}\text { 46.因為我想增進全世界人們的相互理解, 所以我學華語文 } \\
\text { 世界中の人々の相互理解を助けるために、中国語を学んで } \\
\text { います。 } \\
\text { I learn Chinese because I want to increase the mutual un- } \\
\text { derstanding among peoples in the world. }\end{array}$ & $\begin{array}{l}\text { Above } \\
80 \% \\
\text { 以上 } \\
\square\end{array}$ & $60 \sim 79 \%$ & $40 \sim 59 \%$ & $20 \sim 39 \%$ & $\begin{array}{c}\text { Under } \\
19 \% \\
\text { 以下 } \\
\square\end{array}$ \\
\hline 47.我學華語文是為了讓世界各國更了解我的國家。 & Above & $60 \sim 79 \%$ & $40 \sim 59 \%$ & $20 \sim 39 \%$ & Under \\
\hline
\end{tabular}




\begin{tabular}{|c|c|c|c|c|c|}
\hline $\begin{array}{l}\text { 世界中の国々に母国のことを理解してもらうために、中国 } \\
\text { 語を学んでいます。 } \\
\text { I learn Chinese to let the world know more about my coun- } \\
\text { try. }\end{array}$ & $\begin{array}{l}80 \% \\
\text { 以上 } \\
\square\end{array}$ & $\square$ & $\square$ & $\square$ & $\begin{array}{l}19 \% \\
\text { 以下 } \\
\square\end{array}$ \\
\hline $\begin{array}{l}\text { 48.學華語文能讓我有工作升遷的機會。 } \\
\text { 仕事で出世するために、中国語を学んでいます。 } \\
\text { Learning Chinese will give me higher status in my job. }\end{array}$ & $\begin{array}{l}\text { Above } \\
80 \% \\
\text { 以上 } \\
\square\end{array}$ & $60 \sim 79 \%$ & $40 \sim 59 \%$ & $20 \sim 39 \%$ & $\begin{array}{l}\text { Under } \\
19 \% \\
\text { 以下 } \\
\square\end{array}$ \\
\hline $\begin{array}{l}\text { 49.我學華語文是為了達到工作目標。 } \\
\text { 仕事上の目標を達成するために、中国語を学んでいます。 } \\
\text { I learn Chinese in order to achieve an occupational goal. }\end{array}$ & $\begin{array}{l}\text { Above } \\
80 \% \\
\text { 以上 } \\
\square\end{array}$ & $60 \sim 79 \%$ & $40 \sim 59 \%$ & $20 \sim 39 \%$ & $\begin{array}{l}\text { Under } \\
19 \% \\
\text { 以下 } \\
\square\end{array}$ \\
\hline $\begin{array}{l}\text { 50.因為之前念書階段並沒有華語文課，所以我現在才學。 } \\
\text { 以前の学校では中国語の授業がなかつたので、今中国語を } \\
\text { 学んでいます。 } \\
\text { I learn Chinese because no Chinese courses were offered } \\
\text { during previous education. }\end{array}$ & $\begin{array}{l}\text { Above } \\
80 \% \\
\text { 以上 } \\
\square\end{array}$ & $60 \sim 79 \%$ & $40 \sim 59 \%$ & $20 \sim 39 \%$ & $\begin{array}{c}\text { Under } \\
19 \% \\
\text { 以下 } \\
\square\end{array}$ \\
\hline $\begin{array}{l}\text { 51.因為我想成為母國的華語文人才，所以我學華語文。 } \\
\text { 母国で中国語を話せる人材となるために、中国語を学んで } \\
\text { います。 } \\
\text { I learn Chinese because I want to be part of the Chinese re- } \\
\text { source in my country. }\end{array}$ & $\begin{array}{c}\text { Above } \\
80 \% \\
\text { 以上 } \\
\square\end{array}$ & $60 \sim 79 \%$ & $40 \sim 59 \%$ & $20 \sim 39 \%$ & $\begin{array}{c}\text { Under } \\
19 \% \\
\text { 以下 } \\
\square\end{array}$ \\
\hline $\begin{array}{l}\text { 52.因為我想對母國的經濟繁榮有所貢獻, 所以我學華語文 } \\
\text { 母国の経済発展に貢献したいので、中国語を学んでいます } \\
\text { I learn Chinese because I can contribute to my country's } \\
\text { economic prosperity. }\end{array}$ & $\begin{array}{c}\text { Above } \\
80 \% \\
\text { 以上 } \\
\square\end{array}$ & $60 \sim 79 \%$ & $40 \sim 59 \%$ & $20 \sim 39 \%$ & $\begin{array}{c}\text { Under } \\
19 \% \\
\text { 以下 } \\
\square\end{array}$ \\
\hline $\begin{array}{l}\text { 53.因為我想讓老師知道我能用華語文, 所以我學華語文。 } \\
\text { 先生に私が中国語を学ぶことができると知つてほしいので } \\
\text { 、中国語を学んでいます。 } \\
\text { I learn Chinese because I want to show my teachers that I } \\
\text { can learn Chinese. }\end{array}$ & $\begin{array}{c}\text { Above } \\
80 \% \\
\text { 以上 } \\
\square\end{array}$ & $60 \sim 79 \%$ & $40 \sim 59 \%$ & $20 \sim 39 \%$ & $\begin{array}{c}\text { Under } \\
19 \% \\
\text { 以下 } \\
\square\end{array}$ \\
\hline $\begin{array}{l}\text { 54.我學華語文是為了跟我的小孩說話。 } \\
\text { 自分の子供との会話をスムーズにするために、中国語を学 } \\
\text { んでいます。 } \\
\text { Learning Chinese helps me communicate with my children. }\end{array}$ & $\begin{array}{l}\text { Above } \\
80 \% \\
\text { 以上 } \\
\square\end{array}$ & $60 \sim 79 \%$ & $40 \sim 59 \%$ & $20 \sim 39 \%$ & $\begin{array}{l}\text { Under } \\
19 \% \\
\text { 以下 } \\
\square\end{array}$ \\
\hline $\begin{array}{l}\text { 55.我學華語文是為了跟得上我的小孩。 } \\
\text { 自分の子供についていくために、中国語を学びます。 } \\
\text { I learn Chinese to keep up with my children. }\end{array}$ & $\begin{array}{l}\text { Above } \\
80 \% \\
\text { 以上 } \\
\square\end{array}$ & $60 \sim 79 \%$ & $40 \sim 59 \%$ & $20 \sim 39 \%$ & $\begin{array}{l}\text { Under } \\
19 \% \\
\text { 以下 } \\
\square\end{array}$ \\
\hline $\begin{array}{l}\text { 56.我學華語文是為了幫我的小孩學華語文。 } \\
\text { 自分の子供の中国語の勉強を助けるために、中国語を学ん } \\
\text { でいます。 } \\
\text { I learn Chinese to help my children learn Chinese. }\end{array}$ & $\begin{array}{l}\text { Above } \\
80 \% \\
\text { 以上 } \\
\square\end{array}$ & $60 \sim 79 \%$ & $40 \sim 59 \%$ & $20 \sim 39 \%$ & $\begin{array}{c}\text { Under } \\
19 \% \\
\text { 以下 } \\
\square\end{array}$ \\
\hline
\end{tabular}




\begin{tabular}{|c|c|c|c|c|c|}
\hline $\begin{array}{l}\text { 57.我學華語文是為了回答我小孩的問題。 } \\
\text { 自分の子供の質問に答えられるように、中国語を学んでい } \\
\text { ます。 } \\
\text { I learn Chinese to answer questions asked by my children. }\end{array}$ & $\begin{array}{l}\text { Above } \\
80 \% \\
\text { 以上 } \\
\square\end{array}$ & $60 \sim 79 \%$ & $40 \sim 59 \%$ & $20 \sim 39 \%$ & $\begin{array}{l}\text { Under } \\
19 \% \\
\text { 以下 } \\
\square\end{array}$ \\
\hline $\begin{array}{l}\text { 58.我學華語文是為了提升我的工作能力。 } \\
\text { 自分の仕事のスキルアップのために、中国語を学んでいま } \\
\text { す。 } \\
\text { I learn Chinese to increase my job competence. }\end{array}$ & $\begin{array}{l}\text { Above } \\
80 \% \\
\text { 以上 } \\
\square\end{array}$ & $60 \sim 79 \%$ & $40 \sim 59 \%$ & $20 \sim 39 \%$ & $\begin{array}{l}\text { Under } \\
19 \% \\
\text { 以下 } \\
\square\end{array}$ \\
\hline 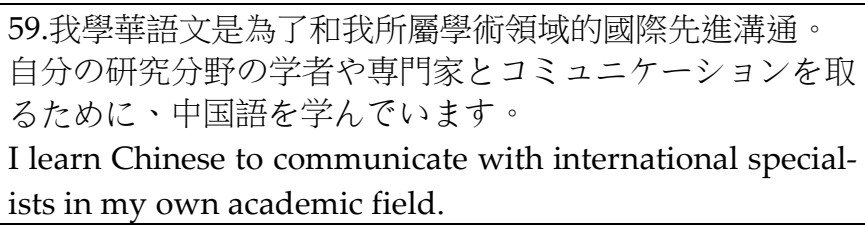 & $\begin{array}{l}\text { Above } \\
80 \% \\
\text { 以上 } \\
\square\end{array}$ & $60 \sim 79 \%$ & $40 \sim 59 \%$ & $20 \sim 39 \%$ & $\begin{array}{c}\text { Under } \\
19 \% \\
\text { 以下 } \\
\square\end{array}$ \\
\hline $\begin{array}{l}\text { 60.我學華語文是為了讀懂我所屬學術領域的研究文獻。 } \\
\text { 自分の研究分野の研究文献を読むために、中国語を学んで } \\
\text { います。 } \\
\text { I learn Chinese to comprehend the research literature in my } \\
\text { own academic field. }\end{array}$ & $\begin{array}{c}\text { Above } \\
80 \% \\
\text { 以上 } \\
\square\end{array}$ & $60 \sim 79 \%$ & $40 \sim 59 \%$ & $20 \sim 39 \%$ & $\begin{array}{c}\text { Under } \\
19 \% \\
\text { 以下 } \\
\square\end{array}$ \\
\hline $\begin{array}{l}\text { 61.我學華語文是為了開闊視野。 } \\
\text { 自分の視野を広げるために、国語を学んでいます。 } \\
\text { I learn Chinese to broaden my horizons. }\end{array}$ & $\begin{array}{c}\text { Above } \\
80 \% \\
\text { 以上 } \\
\square\end{array}$ & $60 \sim 79 \%$ & $40 \sim 59 \%$ & $20 \sim 39 \%$ & $\begin{array}{c}\text { Under } \\
19 \% \\
\text { 以下 } \\
\square\end{array}$ \\
\hline $\begin{array}{l}\text { 62.我學華語文是可以做點什麼, 總比什麼事都沒做來得好 } \\
\text { 。 } \\
\text { 何もせずにいるより何かしていたほうがいいと思うので、 } \\
\text { 中国語を学んでいます。 } \\
\text { I learn Chinese to feel occupied rather than doing nothing. }\end{array}$ & $\begin{array}{c}\text { Above } \\
80 \% \\
\text { 以上 } \\
\square\end{array}$ & $60 \sim 79 \%$ & $40 \sim 59 \%$ & $20 \sim 39 \%$ & $\begin{array}{c}\text { Under } \\
\text { 19\% } \\
\text { 以下 } \\
\square\end{array}$ \\
\hline $\begin{array}{l}\text { 63.我學華語文是為了進到另一所學校或大學就讀。 } \\
\text { 別の学校や大学に入るために、中国語を学んでいます。 } \\
\text { I learn Chinese to get entrance to another school or college. }\end{array}$ & $\begin{array}{c}\text { Above } \\
80 \% \\
\text { 以上 } \\
\square\end{array}$ & $60 \sim 79 \%$ & $40 \sim 59 \%$ & $20 \sim 39 \%$ & $\begin{array}{c}\text { Under } \\
19 \% \\
\text { 以下 } \\
\square\end{array}$ \\
\hline $\begin{array}{l}\text { 64.我父母要我學華語文。 } \\
\text { 私の両親が私に中国語を勉強してほしいと思っています。 } \\
\text { My parents want me to learn Chinese. }\end{array}$ & $\begin{array}{c}\text { Above } \\
80 \% \\
\text { 以上 } \\
\square\end{array}$ & $60 \sim 79 \%$ & $40 \sim 59 \%$ & $20 \sim 39 \%$ & $\begin{array}{c}\text { Under } \\
19 \% \\
\text { 以下 } \\
\square\end{array}$ \\
\hline $\begin{array}{l}\text { 65.學校的學生都要學華語文。 } \\
\text { 私の学校の学生は皆、中国語を学ばなければなりません。 } \\
\text { Everybody in school has to learn Chinese. }\end{array}$ & $\begin{array}{c}\text { Above } \\
80 \% \\
\text { 以上 } \\
\square\end{array}$ & $60 \sim 79 \%$ & $40 \sim 59 \%$ & $20 \sim 39 \%$ & $\begin{array}{c}\text { Under } \\
19 \% \\
\text { 以下 } \\
\square\end{array}$ \\
\hline $\begin{array}{l}\text { 66.我的師長要我學華語文。 } \\
\text { 私の教師が私に中国語を勉強してほしいと思つています。 } \\
\text { My teachers want me to learn Chinese. }\end{array}$ & $\begin{array}{c}\text { Above } \\
80 \% \\
\text { 以上 } \\
\square\end{array}$ & $60 \sim 79 \%$ & $40 \sim 59 \%$ & $20 \sim 39 \%$ & $\begin{array}{c}\text { Under } \\
19 \% \\
\text { 以下 } \\
\square\end{array}$ \\
\hline
\end{tabular}




\begin{tabular}{|c|c|c|c|c|c|}
\hline $\begin{array}{l}\text { 67. 因為我想讓大家知道我說華語文說得很好, 所以我學華 } \\
\text { 語文。 } \\
\text { 周りの人々に、私の中国語は「凄い」と言われたいために } \\
\text { 、中国語を学んでいます。 } \\
\text { I learn Chinese because I want people to think I can speak } \\
\text { Chinese well. }\end{array}$ & $\begin{array}{c}\text { Above } \\
80 \% \\
\text { 以上 } \\
\square\end{array}$ & $60 \sim 79 \%$ & $40 \sim 59 \%$ & $20 \sim 39 \%$ & $\begin{array}{c}\text { Under } \\
19 \% \\
\text { 以下 } \\
\square\end{array}$ \\
\hline $\begin{array}{l}\text { 68.我學華語文是為了了解國際同儕在研討會上用華語文發 } \\
\text { 表的簡報。 } \\
\text { 国際的な会議や研究会で発表される中国語の報告を理解す } \\
\text { るために、中国語を学んでいます。 } \\
\text { I learn Chinese to understand presentations presented in } \\
\text { Chinese by international peers in conferences. }\end{array}$ & $\begin{array}{c}\text { Above } \\
80 \% \\
\text { 以上 } \\
\square\end{array}$ & $60 \sim 79 \%$ & $40 \sim 59 \%$ & $20 \sim 39 \%$ & $\begin{array}{c}\text { Under } \\
19 \% \\
\text { 以下 } \\
\square\end{array}$ \\
\hline $\begin{array}{l}\text { 69.我學華語文是為了不想獨自面對孤寂。 } \\
\text { 孤独になりたくないので、中国語を学んでいます。 } \\
\text { I learn Chinese to get away from loneliness. }\end{array}$ & $\begin{array}{c}\text { Above } \\
80 \% \\
\text { 以上 } \\
\square\end{array}$ & $60 \sim 79 \%$ & $40 \sim 59 \%$ & $20 \sim 39 \%$ & $\begin{array}{c}\text { Under } \\
19 \% \\
\text { 以下 } \\
\square\end{array}$ \\
\hline $\begin{array}{l}\text { 70.我學華語文是為了取得學位。 } \\
\text { 学位を取得するために、中国語を学んでいます。 } \\
\text { I learn Chinese in order to obtain an academic degree. }\end{array}$ & $\begin{array}{c}\text { Above } \\
80 \% \\
\text { 以上 } \\
\square\end{array}$ & $60 \sim 79 \%$ & $40 \sim 59 \%$ & $20 \sim 39 \%$ & $\begin{array}{c}\text { Under } \\
\text { 19\% } \\
\text { 以下 } \\
\square\end{array}$ \\
\hline $\begin{array}{l}\text { 71.因為我認識的人都能說一口流利的華語文, 所以我學華 } \\
\text { 語文。 } \\
\text { 知り合いがみんな流暢に中国語を話せるので、私も中国語 } \\
\text { を学んでいます。 } \\
\text { I learn Chinese because people I am acquainted with can } \\
\text { speak Chinese fluently. }\end{array}$ & $\begin{array}{c}\text { Above } \\
80 \% \\
\text { 以上 } \\
\square\end{array}$ & $60 \sim 79 \%$ & $40 \sim 59 \%$ & $20 \sim 39 \%$ & $\begin{array}{c}\text { Under } \\
\text { 19\% } \\
\text { 以下 } \\
\square\end{array}$ \\
\hline $\begin{array}{l}\text { 72.因為我認識的人也學華語文, 所以我學華語文。 } \\
\text { 知り合いも中国語を学んでいるので、私も中国語を学んで } \\
\text { います。 } \\
\text { I learn Chinese because the people I am familiar with also } \\
\text { learn Chinese. }\end{array}$ & $\begin{array}{c}\text { Above } \\
80 \% \\
\text { 以上 } \\
\square\end{array}$ & $60 \sim 79 \%$ & $40 \sim 59 \%$ & $20 \sim 39 \%$ & $\begin{array}{c}\text { Under } \\
19 \% \\
\text { 以下 } \\
\square\end{array}$ \\
\hline $\begin{array}{l}\text { 73.我學華語文是為了在例行的家庭或工作中得到喘息。 } \\
\text { 家事や仕事で毎日が忙しいため、気分転換に、中国語を学 } \\
\text { んでいます。 } \\
\text { I learn Chinese to have a break from home or work routine. }\end{array}$ & $\begin{array}{l}\text { Above } \\
80 \% \\
\text { 以上 } \\
\square\end{array}$ & $60 \sim 79 \%$ & $40 \sim 59 \%$ & $20 \sim 39 \%$ & $\begin{array}{l}\text { Under } \\
19 \% \\
\text { 以下 } \\
\square\end{array}$ \\
\hline $\begin{array}{l}\text { 74.我學華語文是為了改變我的家庭而做準備。 } \\
\text { 家庭環境の変化に対する準備として、中国語を学んでいま } \\
\text { す。 } \\
\text { I learn Chinese to get ready for changes in my family. }\end{array}$ & $\begin{array}{l}\text { Above } \\
80 \% \\
\text { 以上 } \\
\square\end{array}$ & $60 \sim 79 \%$ & $40 \sim 59 \%$ & $20 \sim 39 \%$ & $\begin{array}{l}\text { Under } \\
19 \% \\
\text { 以下 } \\
\square\end{array}$ \\
\hline $\begin{array}{l}\text { 75.我學華語文是為了跟上家裡的其他人。 } \\
\text { 家族についていくために、中国語を学んでいます。 } \\
\text { I learn Chinese to keep up with others in my family. }\end{array}$ & $\begin{array}{l}\text { Above } \\
80 \% \\
\text { 以上 } \\
\square\end{array}$ & $60 \sim 79 \%$ & $40 \sim 59 \%$ & $20 \sim 39 \%$ & $\begin{array}{c}\text { Under } \\
19 \% \\
\text { 以下 } \\
\square\end{array}$ \\
\hline $\begin{array}{l}\text { 76.我學華語文是為了以後找到好的工作。 } \\
\text { 将来良い仕事につくために、中国語を学んでいます。 }\end{array}$ & $\begin{array}{l}\text { Above } \\
80 \%\end{array}$ & $60 \sim 79 \%$ & $40 \sim 59 \%$ & $20 \sim 39 \%$ & $\begin{array}{c}\text { Under } \\
19 \%\end{array}$ \\
\hline
\end{tabular}




\begin{tabular}{|c|c|c|c|c|c|}
\hline I learn Chinese to find a good job later. & $\begin{array}{c}\text { 以上 } \\
\square\end{array}$ & $\square$ & $\square$ & $\square$ & $\begin{array}{c}\text { 以下 } \\
\square\end{array}$ \\
\hline $\begin{array}{l}\text { 77.我學華語文是為了避免無聊。 } \\
\text { 退屈さをまぎらわすために、中国語を学びます。 } \\
\text { I learn Chinese to get away from boredom. }\end{array}$ & $\begin{array}{l}\text { Above } \\
80 \% \\
\text { 以上 } \\
\square\end{array}$ & $\begin{array}{l}60 \sim 79 \% \\
\square\end{array}$ & $40 \sim 59 \%$ & $20 \sim 39 \%$ & $\begin{array}{l}\text { Under } \\
19 \% \\
\text { 以下 } \\
\square\end{array}$ \\
\hline $\begin{array}{l}\text { 78.因為我的另一半要我學華語文，所以我學華語文。 } \\
\text { 配偶者が私に中国語を学んでほしいと思つているので、中 } \\
\text { 国語を学んでいます。 } \\
\text { I learn Chinese because my spouse wants me to learn it. }\end{array}$ & $\begin{array}{l}\text { Above } \\
80 \% \\
\text { 以上 } \\
\square\end{array}$ & $60 \sim 79 \%$ & $\begin{array}{l}40 \sim 59 \% \\
\square\end{array}$ & $\begin{array}{l}20 \sim 39 \% \\
\square\end{array}$ & $\begin{array}{l}\text { Under } \\
19 \% \\
\text { 以下 } \\
\square\end{array}$ \\
\hline $\begin{array}{l}\text { 79.我學華語文是為了和另一半分享共通的興趣。 } \\
\text { 配偶者と同じ趣味を共有するために、中国語を学んでいま } \\
\text { す。 } \\
\text { I learn Chinese to share a common interest with my spouse. }\end{array}$ & $\begin{array}{l}\text { Above } \\
80 \% \\
\text { 以上 } \\
\square\end{array}$ & $60 \sim 79 \%$ & $40 \sim 59 \%$ & $20 \sim 39 \%$ & $\begin{array}{l}\text { Under } \\
19 \% \\
\text { 以下 } \\
\square\end{array}$ \\
\hline $\begin{array}{l}\text { 80.如果在華語文課裡不能說華語文，我會覺得不高興。 } \\
\text { 授業中で中国語を発話しないと、落ち込んだり悔しかった } \\
\text { りします。 } \\
\text { I feel bad if I couldn't speak Chinese in Chinese classes. }\end{array}$ & $\begin{array}{l}\text { Above } \\
80 \% \\
\text { 以上 } \\
\square\end{array}$ & $60 \sim 79 \%$ & $40 \sim 59 \%$ & $20 \sim 39 \%$ & $\begin{array}{l}\text { Under } \\
19 \% \\
\text { 以下 } \\
\square\end{array}$ \\
\hline $\begin{array}{l}\text { 81.因為我喜歡學習新知，所以我學華語文。 } \\
\text { 新しい知識を学ぶことが好きなので、中国語を学んでいま } \\
\text { す。 } \\
\text { I learn Chinese because I like learning new things. }\end{array}$ & $\begin{array}{l}\text { Above } \\
80 \% \\
\text { 以上 } \\
\square\end{array}$ & $60 \sim 79 \%$ & $40 \sim 59 \%$ & $20 \sim 39 \%$ & $\begin{array}{l}\text { Under } \\
19 \% \\
\text { 以下 } \\
\square\end{array}$ \\
\hline $\begin{array}{l}\text { 82.我學華語文是為了考試得高分。 } \\
\text { 試験で良い点数を取るために、中国語を学んでいます。 } \\
\text { I learn Chinese in order to obtain high scores in examina- } \\
\text { tions. }\end{array}$ & $\begin{array}{l}\text { Above } \\
80 \% \\
\text { 以上 } \\
\square\end{array}$ & $60 \sim 79 \%$ & $\begin{array}{l}40 \sim 59 \% \\
\square\end{array}$ & $20 \sim 39 \%$ & $\begin{array}{l}\text { Under } \\
19 \% \\
\text { 以下 } \\
\square\end{array}$ \\
\hline $\begin{array}{l}\text { 83.我學華語文是為了通過考試。 } \\
\text { 試験に合格するために、中国語を学んでいます。 } \\
\text { I learn Chinese to pass examinations. }\end{array}$ & $\begin{array}{c}\text { Above } \\
80 \% \\
\text { 以上 } \\
\square\end{array}$ & $60 \sim 79 \%$ & $40 \sim 59 \%$ & $20 \sim 39 \%$ & $\begin{array}{c}\text { Under } \\
19 \% \\
\text { 以下 } \\
\square\end{array}$ \\
\hline $\begin{array}{l}\text { 84.我學華語文是為了得到到成就感。 } \\
\text { 達成感がほしいために、中国語を学んでいます。 } \\
\text { I learn Chinese to feel a sense of achievement. }\end{array}$ & $\begin{array}{c}\text { Above } \\
80 \% \\
\text { 以上 } \\
\square\end{array}$ & $60 \sim 79 \%$ & $40 \sim 59 \%$ & $20 \sim 39 \%$ & $\begin{array}{c}\text { Under } \\
\text { 19\% } \\
\text { 以下 } \\
\square\end{array}$ \\
\hline $\begin{array}{l}\text { 85.因為獲得好的華語文技能是人生成功的熱腳石, 所以我 } \\
\text { 學華語文。 } \\
\text { 優れた中国語のスキルを身につけることは、人生を成功へ } \\
\text { と導く足がかりになるので、中国語を学んでいます。 } \\
\text { I learn Chinese because acquiring good Chinese skills is a } \\
\text { stepping-stone to one's success in life. }\end{array}$ & $\begin{array}{c}\text { Above } \\
80 \% \\
\text { 以上 } \\
\square\end{array}$ & $60 \sim 79 \%$ & $40 \sim 59 \%$ & $20 \sim 39 \%$ & $\begin{array}{c}\text { Under } \\
19 \% \\
\text { 以下 } \\
\square\end{array}$ \\
\hline 86.因為我想挑戰一個有難度的外語，所以我學華語文。 & Above & $60 \sim 79 \%$ & $40 \sim 59 \%$ & $20 \sim 39 \%$ & Under \\
\hline
\end{tabular}




\begin{tabular}{|l|c|c|c|c|}
\hline 難しい外国語に挑戦したいので、中国語を学んでいます。 & $80 \%$ & & $19 \%$ \\
I learn Chinese because learning Chinese can challenge me. & $\begin{array}{c}\text { 以上 } \\
\text { 以下 }\end{array}$ & $\square$ & $\square$ & $\square$ \\
\hline
\end{tabular}

87.如果你（妳）還有其他學習華語文的動機, 請寫下來。

他の中国語を学ぶ動機があれば、ここに書いてください。

Please write down here if you have other motivations for studying Chinese.

Note: All items in this Q-JLMLC for formal survey were revised and scrambled based on the expert judgement.

\section{二、個人基本資料 個人のプロフィール Personal profile}

1.性別 性別 Gender：口男 男 Male 口女女 Female

2.年齡 年齢 Age : 歲 歳 years old

3.身分 身分 Identity:

口小學生 小学生 Pupil

口中學生 中学生 Middle school student

口高中生 高校生 High school student

口專科生 専門学校生 Junior college student

口大學生 大学生 Undergraduate

口碩士生 修士課程在学中 Postgraduate

㗘士生 (含博士候選人) 博士課程在学中 Doctoral student/ candidate

口上班族 社会人 Office worker

口退休人員 退職者 Retiree

唭他その他 Others :

4.國籍身分 国籍 Nationality:

口日本人 日本人 Japanese

昍本華裔 日本の華僑 Japanese-born Chinese

昍本亞裔 在日アジア系 Japanese-born Asian

唭他その他 Others：

5.現就讀學校或服務單位：

学校や所属機関 :

School or affiliation:

6.婚姻狀況 結婚歴 Marital status：

口已婚 既婚 Married :

另一半是哪國人?

配偶者はどこの国の人ですか。

Nationality of your spouse?

育有子女幾位?

男女

子供は何人いますか。男 
Number of children?

Boy Girl

小孩是否也在學華語文?口是 口否

子供も中国語を学んでいますか。林林

Are your children learning Chinese now? $\square$ Yes $\square$ No

口未婚 未婚 unmarried

唭他 その他 Others：

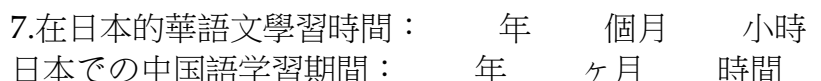

How long have you learned Chinese in Japan? Year(s) month(s) hour(s)

8.在哪些國家學過華語文?

母国以外で中国語を学んだ経験がありますか。

Where else have you learned Chinese?

口臺灣：華語文學習時間：年 個月小時

咍湾：中国語学習期間：年邱時間

口Taiwan: How long? year(s) month(s) hour(s)

口中國大陸：華語文學習時間：年 個月小時

口中国：中国語学習期間：年ケ月＼cjkstart時間

$\square$ Mainland China: How long? year(s) month(s) hour(s)

唭他：：華語文學習時間：年 個月 小時

$\begin{array}{lrrrr}\text { 口その他：中国語学習期間： } & \text { 年 } & \text { ケ月 } & \text { 時間 } & \\ \text { 口Others: } & \text { :How long? } & \text { year(s) } & \text { month(s) } & \text { hour(s) }\end{array}$

9.自評華語文程度（若考過中國語檢定、中國的 HSK 或臺灣的 TOCFL, 請依通過的程度填寫)：

中国語能力の自己評価（日本の中国語検定、中国の HSK、台湾の TOCFL に合格している人は、合格した級に応じた レベルを記入して下さい。) :

Self-evaluation on Chinese level (Please tick the item "Testing Chinese Proficiency, Japan”, HSK, or TOCFL if you passed any of them):

聽：口零起點 口初級 口中級 口高級 口其他：

聞く：ロゼロ ロ初級 口中級 上級 ロその他：

Listening: $\square$ Zero $\square$ Basic $\square$ Intermediate $\square$ Advanced $\square$ Others:

說：口零起點口初級 口中級 口高級 口其他：

話す：ロゼロ ロ初級 ロ中級 ロ上級 ロその他：

Speaking: $\square$ Zero $\square$ Basic $\square$ Intermediate $\square$ Advanced $\square$ Others:

讀：口零起點口初級口中級口高級口其他：

読む：ロゼロ ロ初級 ロ中級口上級口その他：

Reading: $\square$ Zero $\square$ Basic $\square$ Intermediate $\square$ Advanced $\square$ Others:

寫：口零起點口初級口中級口高級口其他：

書く：ロゼロ ロ初級 ロ中級 ロ上級 ロその他：

Writing: $\square$ Zero $\square$ Basic $\square$ Intermediate $\square$ Advanced $\square$ Others:

綜合：口零起點 口初級口中級口高級 口其他：

総合：ロゼロ ロ初級 口中級 口上級 ロその他：

Synthesis: $\square$ Zero $\square$ Basic $\square$ Intermediate $\square$ Advanced $\square$ Others:

Note: All items in this Q-JLMLC for formal survey were revised and scrambled based on the expert judgement. 


\section{References}

1. Buchner, J.; Kerres, M. Students as Designers of Augmented Reality: Impact on Learning and Motivation in Computer Science. Multimodal Technol. Interact 2021, 5(8), 41-56. [CrossRef]

2. Kovas, Y.; Garon-Carrier, G.; Boivin, M.; Petrill, S. A.; Plomin, R.; Malykh, S. B.; Spinath, F.; Murayama, K.; Ando, J.; Bogdanova, O. Y.; Brendgen, M.; Dionne, G.; Forget-Dubois, N.; Galajinsky, E. V.; Gottschling, J.; Guay, F.; Lemelin, J.-P.; Logan, J. A. R.; Yamagata, S.; Shikishima, C.; Spinath, B.; Thompson, L. A.; Tikhomirova, T. N.; Tosto, M. G.; Tremblay, R.; Vitaro, F. Why Children Differ in Motivation to Learn: Insights from over 13,000 Twins from 6 Countries. Personality and Individual Differences 2015, 80, 51-63. [CrossRef]

3. Rodríguez, S.; Regueiro, B.; Piñeiro, I.; Valle, A.; Sánchez, B.; Vieites, T.; Rodríguez-Llorente, C. Success in Mathematics and Academic Wellbeing in Primary-School Students. Sustainability 2020, 12, 3796-3806. [CrossRef]

4. Smith, J.; Guimond, F.-A.; Bergeron, J.; St-Amand, J.; Fitzpatrick, C.; Gagnon, M. Changes in Students' Achievement Motivation in The Context of the COVID-19 Pandemic: A Function of Extraversion/Introversion? Education Science 2021, 11, 30-37. [Cross$\underline{\text { Ref] }}$

5. Toli, G.; Kallery, M. Enhancing Student Interest to Promote Learning in Science: The Case of The Concept of Energy. Education Science 2021, 11, 220-234. [CrossRef]

6. Vergara, D.; María Luz Fernández, M. L.; Lorenzo, M. Enhancing Student Motivation in Secondary School Mathematics Courses: A Methodological Approach. Education Science 2019, 9, 83-93. [CrossRef]

7. Almulla, M. A.; Alamri, M. M. Using Conceptual Mapping for Learning to Affect Students' Motivation and Academic Achievement. Sustainability 2021, 13, 4029-4045. [CrossRef]

8. Blašková, M.; Majchrzak-Lepczyk, J.; Dominika Hriníková, D.; Blaško, R. Sustainable Academic Motivation. Sustainability 2019, 11, 5934-5957. [CrossRef]

9. Santamaría-Vázquez, M.; Líbano, M. D.; Martínez-Lezaun, I.; Ortiz-Huerta, J. H. Self-Regulation of Motivation and Confinement by COVID-19: A Study in Spanish University Students. Sustainability 2021, 13, 5435-5448. [CrossRef]

10. Dörnyei, Z. The Psychology of Second Language Acquisition; Oxford University Press: Oxford, United Kingdom, 2009. [CrossRef]

11. Duru, I.; Sunar, A. S.; White, S.; Diri, B.; Dogan, G. A Case Study on English as A Second Language Speakers for Sustainable MOOC Study. Sustainability 2019, 11, 2808-2831. [CrossRef]

12. Gong, Y. (F.); Ma, M.; Hsiang, T. P.; Wang, C. Sustaining International Students' Learning of Chinese in China: Shifting Motivations among New Zealand Students during Study Abroad. Sustainability 2020, 12, 6289-6302. [CrossRef]

13. Liu, M.; Zheng, Y.; Ma, X.; Wei, Y. Sustaining Multilingualism in Chinese Universities: Uzbekistani Students' Demotivation While Learning Chinese. Sustainability 2020, 12, 7570-7585. [CrossRef]

14. Peng, J.-E.; Xie, X. (S.). English-Medium Instruction as A Pedagogical Strategy for The Sustainable Development of EFL Learners in The Chinese Context: A Meta-Analysis of Its Effectiveness. Sustainability 2021, 13, 5637-5656. [CrossRef]

15. Sárdi, C. Sustaining Long-Term L2 and L3 Learning Motivation in A Monolingual Environment. In International Research on Multilingualism: Breaking with The Monolingual Perspective; Vetter E., Jessner U., Eds.; Springer: Cham, Switzerland, 2019; Multilingual Education Volume 35, pp. 215-232. [CrossRef]

16. Nin, R.;Cai, Q.-Y. Exploring for Japanese University Students' Motivation for Participating in Learning Chinese. Chung Yuan Journal of Teaching Chinese as a Second Language 2009, 4, 185-201. [CrossRef]

17. Ding, A. Q.; Wu, S. N. An Empirical Study on Learners of Chinese as A Second Language; World Publishing: Beijing, China, 2011.

18. Gao, Y. D.; Li, G. Q.; Guo, X. A Report on The Survey Study about Foreigners' Learning and Using Chinese Language; Beijing Language and Culture University: Beijing, China, 1993.

19. Shi, D. G.; Wan, Y. X. An Investigation Report on Teaching Chinese as A Foreign Language. Language Teaching and Linguistic Studies 1998, 1, 36-48.

20. Tan, X.-j. Comments on the Learning Motivation Research in Learning Chinese as A Second Language in The Past 30 Years in China and Abroad. Journal of Kunming University of Science and Technology (Social Science Edition) 2015, 2, 94-101.

21. He, G. J. Viewing Teaching Chinese as A Foreign Language from The Situation of International Students in Wuhan of China. Journal of Inner Mongolia Normal University (Educational Science) 2003, 16(2), 92-94.

22. Xia, M. G. An Analysis of Chinese Heritage Language Students ' Motivation in Learning Chinese. Journal of Urumqi Adult Education Institute 2003, 4, 46-54.

23. Hou, C. C. Factors Affecting Chinese Learning Motivation of Central Asian Students. Education for Chinese After-school (Theory) 2008, 2, 23-24.

24. Xu, Z.-L. Research on Cognitive Theory for Teaching Chinese as A Foreign Language; Sinolingua: Beijing, China, 2000.

25. Lu, B. S. Introduction to Teaching Chinese as A Foreign Language (Handout); Office of the Qualification Review Committee for Teachers of Chinese as a Foreign Language, Ministry of Education: Beijing, China, 1999.

26. Li, Y. M. Language Learning Needs and Teaching Chinese as A Foreign Language. Teaching Chinese as a Foreign Language 2006, 1, $1-7$.

27. Tsai, Y. H.; Shu, Z.-m.; Chen, L.-F.; Chang, H. Y.; Ho, S.-c.; Lai, M.-t. Introduction to Teaching Chinese as A Second Language; San Min Book: Taipei, Taiwan, 2014. 
28. Xue, M.; Chen, Y. H. The Consciousness of Language Use of Chinese Children Living in Japan and Their Ethnicity: From A Survey in A Chinese School. Language and Culture: Bulletin of Institute for Language Education of Aichi University 2012, 53(26), 31-49.

29. Hiraoka, K.; Okuda, H.; Kawasaki, E. The Relationship between High School Students' Motivation to Learn Chinese and Their Grades. Annual convention of the Japanese Association of Educational Psychology 2006, 48, 50.

30. Sugie, S. Practice of The Communicative Blended E-Learning for Chinese Class at High School in Japan. 2012. Available online: https://eprints.lib.hokudai.ac.jp/dspace/bitstream/2115/55797/3/JSiSE2012ID_BL_CFL_sugie0607.pdf (accessed on 2 August 2020).

31. Xia, Q. Investigation and Analysis for Chinese Learning Purposes of Foreign Students in China's Schools. Science E Technology Economy Market 2007, 7, 224.

32. An, N. A Motivational Model for Japanese University Students' Learning of Chinese. Kyoto University Research Studies in Education 2003, 49, 314-326.

33. An, N. Motivation, Goal Orientation, Learning Activities, Pedagogical Preferences, and Performance in Learning Chinese. Kyoto University Research Studies in Education 2004, 50, 227-240.

34. Kuo, C. G.; Liu, G. B. The Japanese Student's Consciousness of China through Studying Chinese at University. Studies in the Humanities and Sciences 2007, 48(1), 181-193.

35. Li, Y. A Chinese Study Seen from Psychological Aspects-With Special Emphasis on A Questionnaire of University Students. Doshisha Studies in Language and Culture 2004, 7, 65-88.

36. Mao, H.; Fukuda, N. A Comparison on Learning Motivation between Major Japanese Learners in China and Major Chinese Learners in Japan. Language and Culture 2011, 23, 209-232.

37. Tao, L. Investigation and Research on Learning Motives of Japanese-Chinese Learners. Forum of Language Instructors 2014, 8, 8190.

38. Hofer, B. K. Motivation in The College Classroom. In McKeachie's Teaching Tips: Strategies, Research, and Theory for College and University Teachers; McKeachie,W. J., Svinicki, M., Eds.; Houghton Mifflin: Boston, USA, 2006; pp. 140-150.

39. Lam, B.-H.; Kember, D. The Relationship between Conceptions of Teaching and Approaches to Teaching. Teachers and Teaching: Theory and Practice 2006, 12(6), 693-713. [CrossRef]

40. Adams, J.; Corbett, A. Experiences of Traditional and Non-Traditional College Students: A Quantitative Study of Experiences, Motivations and Expectations among Undergraduate Students. 2010. Available online: https://cola.unh.edu/sites/cola.unh.edu/files/studentjournals/JenniferAdams AlexiaCorbett.pdf (accessed on 3 August 2020).

41. Baptista, A.; Bessa, J.; Huet, I.; Tavares, J. Studying Non-Traditional Adult Students' Motivation: A Research at The University of Aveiro. In Teaching and Learning 2008: Proceedings of the IASK International Conference; Organero, M. M., Ed.; International Association for the Scientific Knowledge (IASK): Aveiro, Portugal, 2008; pp. 1-10.

42. Rautopuro, J.; Vaisanen, P. Non-Traditional Students at University: A Follow-up Study of Young and Adult Students' Orientations, Satisfaction and Learning Outcomes. 2001. Available online: http://www.leeds.ac.uk/educol/documents/00001880.htm (accessed on 3 August 2020).

43. Rothes, A.; Lemos, M. S.; Gonçalves, T. Motivational Profiles of Adult Learners. Adult Education Quarterly 2017, 67(1), 329. [CrossRef]

44. Wolfgang, M.; Dowling, W. Differences in Motivation of Adult and Younger Undergraduates. Journal of Higher Education 1981, 52(6), 640-648. [CrossRef]

45. Ardasheva, Y.; Tong, S.; Tretter, T. R. Validating The English Language Learner Motivation Scale (ELLMS) to Measure Language Learning Motivational Orientations among School-Aged ELLs. Learning and Individual Differences 2012, 22(4), 473483. [CrossRef]

46. Boshier, R. Psychometric Properties of The Alternative Form of The Education Participation Scale. Adult Education Journal 1991, 41(3), 150-167. [CrossRef]

47. Lee, S. H. The Difference of Motivation between Korean Learners of Japanese as Second Language and Japanese as Foreign Language. Japanese Language Education Around the Globe 2003, 13, 75-92. [CrossRef]

48. Prihantoro, S. S.; Widyana, R.; Setiawan, E. P. Learner Motivation in ESL Learning Strategies and Gender Role. Language and Language Teaching Journal 2018, 21(1), 1-10. [CrossRef]

49. Schmidt, R.; Boraie, D.; Kassabgy, O. Foreign Language Motivation: Internal Structure and External Connections. In Language Learning Motivation: Pathways to The New Century, Technical Report \#11; Oxford, R., Ed.; University of Hawaii, Second Language Teaching \& Curriculum Center: Honolulu, USA, 1996; pp.9-70.

50. Xu, H.; Gao, Y. The Development of English Learning Motivation and Learners' Identities: A Structural Equation Modeling Analysis of Longitudinal Data from Chinese Universities. System 2014, 47, 102-115. [CrossRef]

51. Waltz, C. F.; Strickland, O. L.; Lenz, E. R. Measurement in Nursing Research, 2nd ed.; F. A. Davis: Philadelphia, USA, 1991.

52. Polit, D. F.; Beck, C. T.; Owen, S. V. Is The CVI An Acceptable Indicator of Content Validity? Appraisal and Recommendations. Research in Nursing \& Health 2007, 30(4): 459-67. [CrossRef]

53. Cooper, D. R.; Schindler, P. S. Business Research Methods; McGraw-Hill Education: New York, USA, 2014.

54. Field, A. Discovering Statistics Using IBM SPSS Statistics, 5th ed.; SAGE Edge: New York, USA, 2018. 
55. Hair Jr., J. F.; Black, W. C.; Babin, B. J.; Anderson, R. E. Multivariate Data Analysis: A Global Perspective, 7th ed.; Pearson Prentice Hall: Upper Saddle River, N.J., USA, 2010.

56. Alfayad, Z.; Arif, L. S. M. Employee Voice and Job Satisfaction: An Application of Herzberg's Two-Factor Theory. International Review of Management and Marketing 2017, 7(1), 150-156.

57. Fornell, C.; Larcker, D. F. Evaluating Structural Equation Models with Unobservable Variables and Measurement Error. Journal of Marketing Research 1981, 18, 39-50. [CrossRef]

58. Torkzadeh, G.; Koufteros, X.; \& Pflughoeft, K. Confirmatory Analysis of Computer SelfEfficacy. Structural Equation Modeling 2003, 10(2), 263-275. [CrossRef]

59. Gardner, R. C.; MacIntyre, P. D. An Instrumental Motivation in Language Study: Who Says It Isn't Effective? Studies in Second Language Acquisition 1991, 13, 57-72. [CrossRef]

60. Hong, Y. C.; Ganapathy, M. To Investigate ESL Students' Instrumental and Integrative Motivation towards English Language Learning in A Chinese School in Penang: Case Study. English Language Teaching 2017, 10(9), 17-35. [CrossRef]

61. Deci, E. L.; Olafsen, A. H.; Ryan, R. M. Self-Determination Theory in Work Organizations: The State of A Science. Annual Review of Organizational Psychology and Organizational Behavior 2017, 4, 19-43. [CrossRef]

62. Gardner, R. Integrative Motivation and Global Language (English) Acquisition in Poland. Studies in Second Language Learning and Teaching 2012, 2(2), 215-226. [CrossRef]

63. Gardner, R. Social Psychology and Second Language Learning: The Role of Attitude and Motivation; Edward Arnold: London, United Kingdom, 1985.

64. Levesque, C.; Copeland, K. J.; Pattie, M. D.; Deci, E. L. Intrinsic and Extrinsic Motivation. In International Encyclopedia of Education, 3rd ed.; Peterson, P. L., Baker, E. L., MacGaw, B., Eds.; Elsevier: Oxford, United Kingdom, 2010; pp. 618-623. [CrossRef]

65. Ariane, R.; Pascale, H. The Impact of Age and Gender on The Learners' Motivation and Attitudes towards French in Secondary Education in Flanders. In Proceedings of INTED2012 Conference; International Association of Technology, Education and Development (IATED), Ed.; IATED: Valencia, Spain, 2012; pp. 0159-0165.

66. Asmali, M. Young Learners' Attitudes and Motivation to Learn English. Novitas-ROYAL (Research on Youth and Language) 2017, 11(1), 53-68.

67. Houle, C. O. The Inquiring Mind-A Study of The Adult Who Continues to Learn, 3rd ed.; Oklahoma Research Center for Continuing Professional and Higher Education, University of Oklahoma: Norman, Okla, USA, 1993.

68. Knowles, M. S.; Holton III, E. F.; Swanson, R. A. The Adult Learner: The Definitive Classic in Adult Education and Human Resource Development; Routledge: New York, USA, 2014.

69. Zhang, Y. O. A Study of Japanese Students' Motivation of Studying Chinese. Forum for Foreign Language Education 2014, 13, 4566.

70. Kuo, C. W. A Case Study on The Types of Chinese Learning Motivation and The Application of Teaching Strategies. Language Education Forum 2014, 2, 15-19.

71. Takahashi, N. 2018. A Study of Japanese Non-Students' Motivation in Learning Chinese as a Foreign Language. Master's thesis, National Taichung University of Education, Taichung, Taiwan.

72. Akçay, A.; Bütüner, T. F.; Arikan, A. Reasons behind Youngers' Learning of Foreign Languages. International Journal of Language Academy 2015, 3(2), 56-68. [CrossRef]

73. Ferrari, L. 2013. The Motivation of Adult Foreign Language Learners on An Italian Beginners' Course: An Exploratory, Longitudinal Study. Ph.D. Dissertation, University of York, York, United Kingdom.

74. Hudson, J. Integrative Motivation and Second Language Learning: The Role of Integrative Motivation among ESOL Learners at A Scottish College. Language Issues, 2017, 28(1), 23-35.

75. Arthur, L.; Beaton, F. Adult Foreign Language Learners: Motivation, Attitudes and Behaviours. Language Learning Journal 2000, 21(1), 31-36. [CrossRef]

76. Noels, K. A.; Pelletier, L. G.; Clément, R.; Vallerand, R. J. Why Are You Learning A Second Language? Motivational Orientations and Self-Determination Theory. Language Learning 2000, 50, 57-85. [CrossRef]

77. Aydogan, H. Intrinsic and Extrinsic Motivation for English Learning Scale (IEM-ELS): A Psycholinguistics Study of Reliability and Validity. Celal Bayar Üniversitesi Sosyal Bilimler Dergisi 2016, 14(3), 55-66. [CrossRef]

78. Wentzel, K. R. Social Relationships and Motivation in Middle School: The Role of Parents, Teachers, and Peers. Journal of Educational Psychology 1998, 90(2), 202-209. [CrossRef]

79. Gao, Y.; Cheng, Y.; Zhao, Y.; Zhou, Y. The Relationship between Types of English Learning Motivation and Motivational Intensity - A Quantitative Investigation on Chinese College Undergraduates. Foreign Languages Research 2003, 1, 60-64.

80. Flowerdew, J.; Peacock, M. Research Perspectives on English for Academic Purposes. Cambridge University Press: Cambridge, United Kingdom, 2001. [CrossRef]

81. British Inter-University China Center. BICC Manchester Chinese for Academic Purposes Week. 2016. Available online: https://www.bicc.ac.uk/2016/04/08/bicc-manchester-chinese-for-academic-purposesweek/ (accessed on 4 August 2020). 
82. Cai, J. Students' Perceptions of Academic Writing: A Needs Analysis of EAP in China. Language Education in Asia 2013, 4(1), 522. [CrossRef]

83. Areepattamannil, S.; Freeman, J. G.; Klinger, D. Influence of Motivation, Self-beliefs, and Instructional Practices on Science Achievement of Adolescents in Canada. Social Psychology of Education 2011, 14(2), 233-259. [CrossRef] 